LBNL-55340

\title{
Distributed Energy Resources at Naval Base Ventura County Building 1512
}

\author{
Prepared for the \\ Federal Energy Management Program \\ Assistant Secretary for Energy Efficiency and Renewable Energy \\ U.S. Department of Energy
}

Principal Authors

Owen C Bailey and Chris Marnay

Ernest Orlando Lawrence Berkeley National Laboratory

1 Cyclotron Road, MS 90R4000

Berkeley CA 94720-8136

October 2004

This work described in this paper was funded by the Assistant Secretary of Energy Efficiency and Renewable Energy, through the Federal Energy Management Program, of the U.S. Department of Energy under Contract No. DE-AC03-76SF00098. 



\section{Acknowledgments}

The work described in this report was funded by the Assistant Secretary of Energy Efficiency and Renewable Energy, through the Federal Energy Management Program, of the U.S. Department of Energy under Contract No. DE-AC03-76SF00098.

The California Energy Commission and the Distributed Energy Program of DOE also provided prior funding to develop and validate the DER-CAM model that was used for this analysis.

We would like to thank the personnel at Naval Base Ventura County who provided considerable assistance by gathering information and by hosting our team, including Tom Santoianni, Bob Demyanovich, Deborah Stewart, and Chris Karandang, at the site. Also, thanks to the team from AEPC Group, LLC for coordinating the initial site visit and their energy audit with Berkeley Lab.

Steve Greenberg and Andy Green from LBNL also helped organize the initial site visit and energy audit, provided background information on NBVC, and answered questions about energy infrastructure at the site.

Many colleagues have worked on the development of DER-CAM and its application in prior studies, including the following: Afzal Siddiqui, Michael Stadler, Ryan M. Firestone, Jennifer L. Edwards, Kristina Hamachi LaCommare, and others. 



\section{Table of Contents}

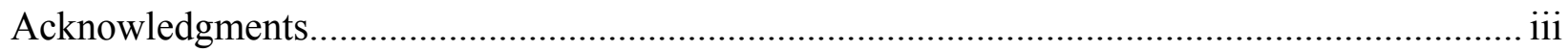

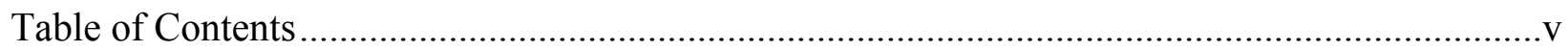

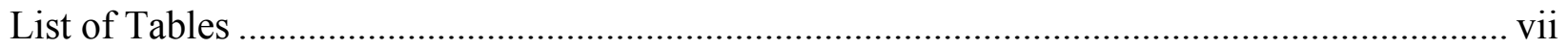

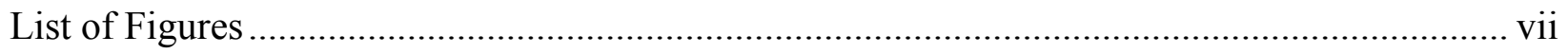

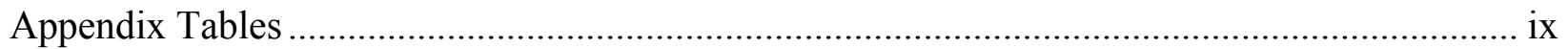

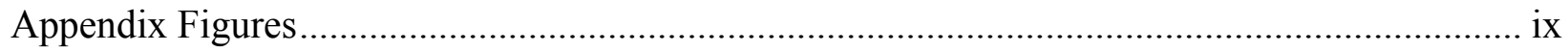

Acronyms and Abbreviations …………………….............................................................. xi

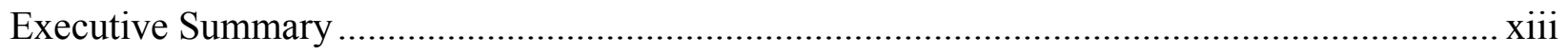

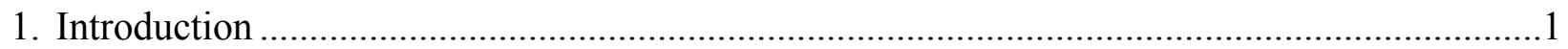

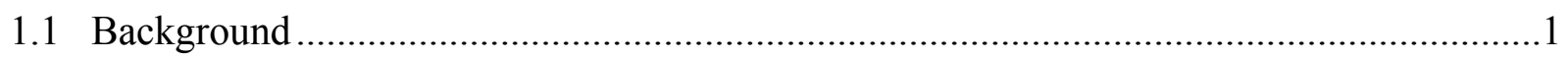

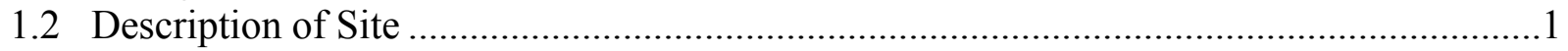

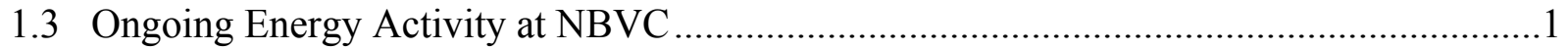

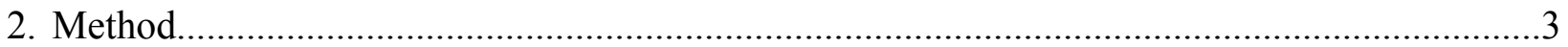

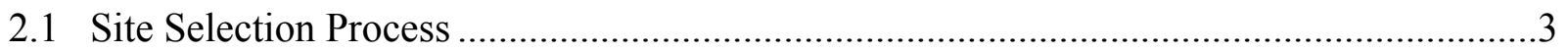

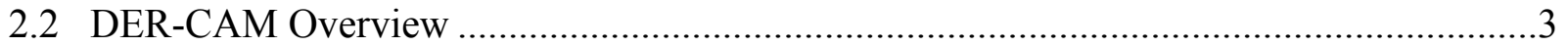

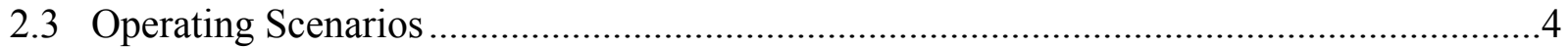

2.4 Load Profiles .......................................................................................................

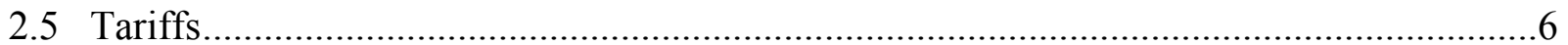

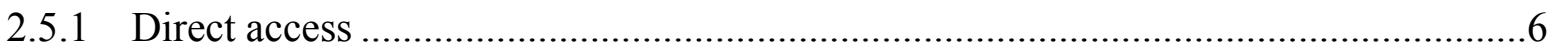

2.5.2 SCE TOU-8

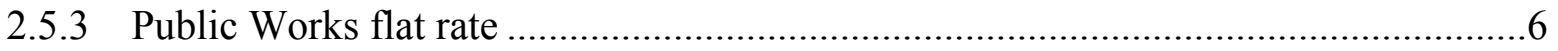

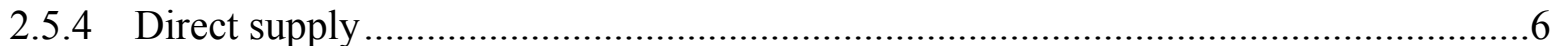

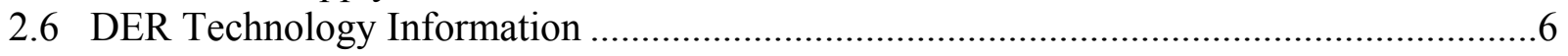

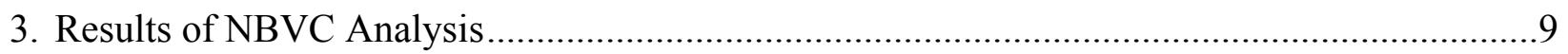

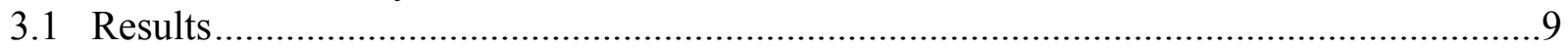

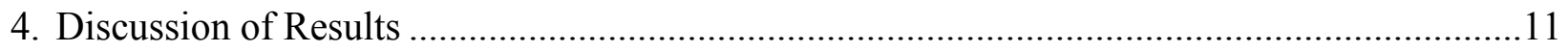

4.1 Scenario 1 Results: No DER Installation....................................................................

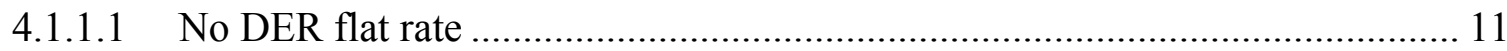

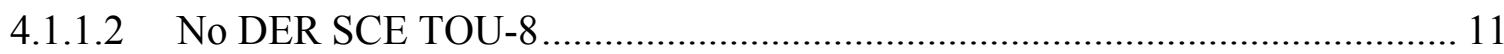

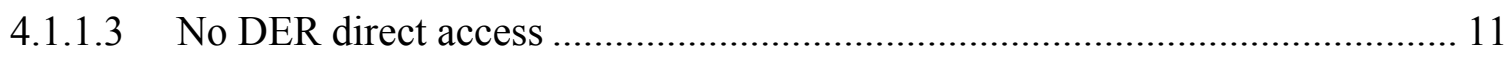

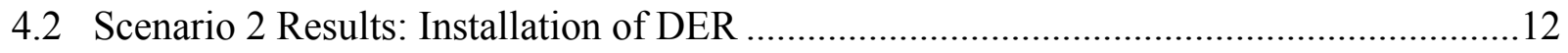

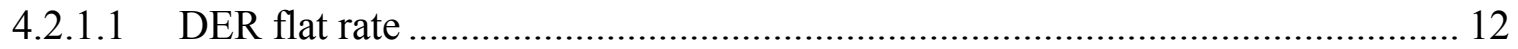

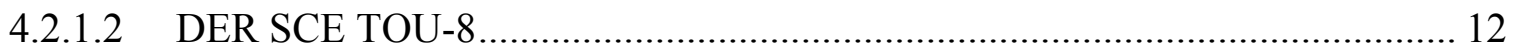




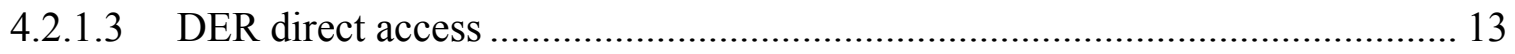

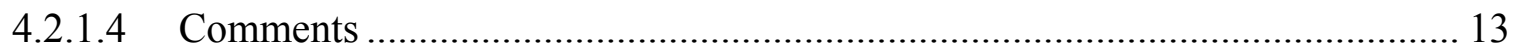

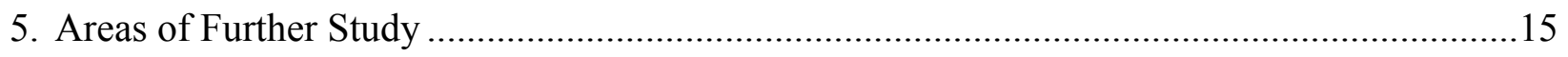

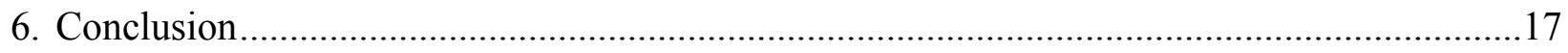

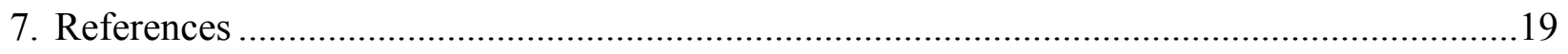

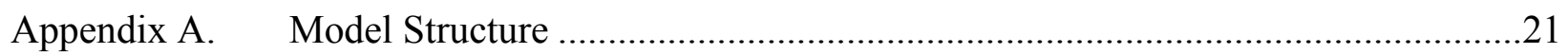

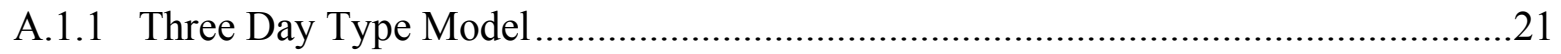

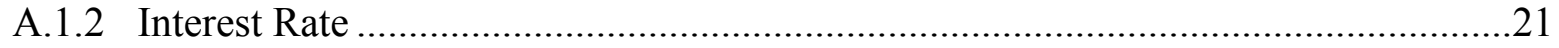

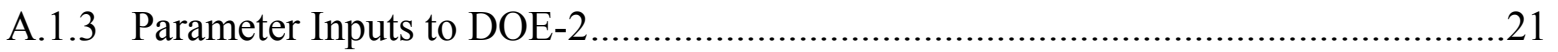

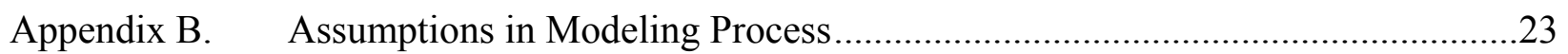

B.1.1 Assumptions made for Modeling Building 1512 at NBVC ...................................23

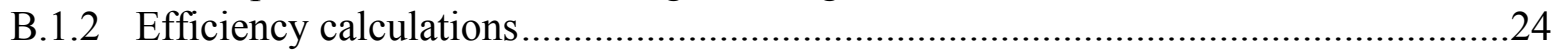

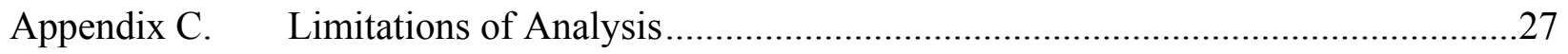

Appendix D. Technology Performance and Price Information...............................................29

D.1 Technology Performance and Price Parameters ……………………………...................2.

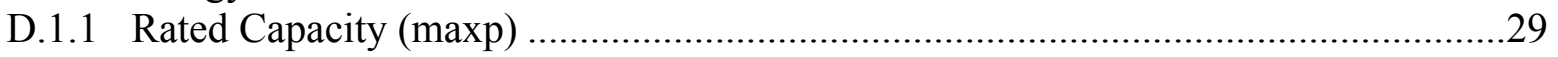

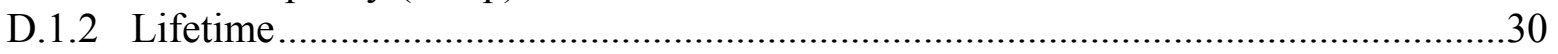

D.1.3 Capital Costs (Capcost)...........................................................................................

D.1.4 Operation and Maintenance Fixed Costs (OMFix)......................................................30

D.1.5 Operation and Maintenance Variable Costs (OMVar) ……......................................30

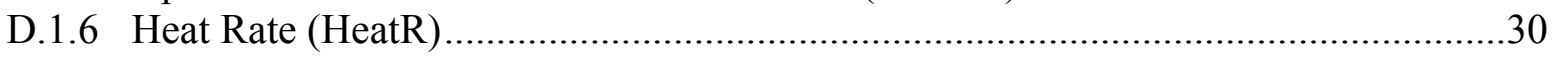

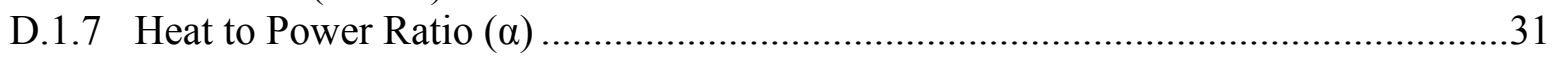

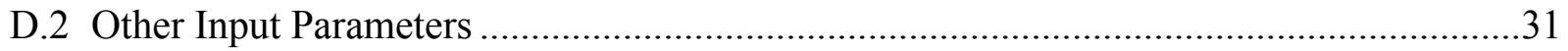

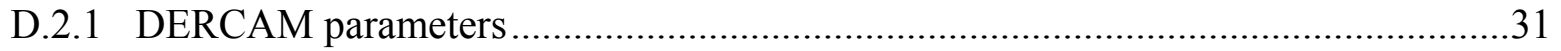

D.2.2 Conversion Efficiency for Recoverable Heat to Load Displacement $(\gamma)$...................31

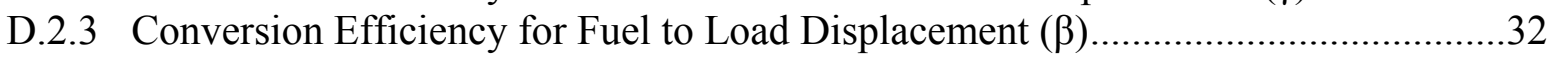

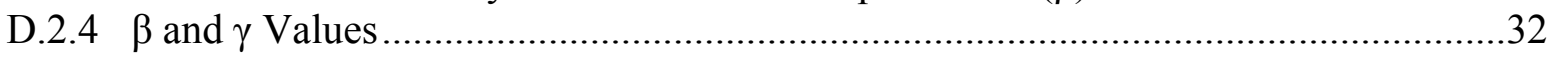

Appendix E. CPUC Self-generation Incentive Program' : ..........................................................35

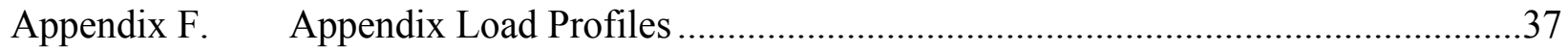

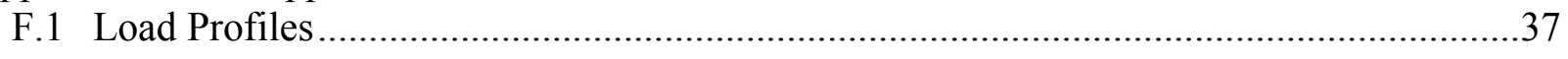

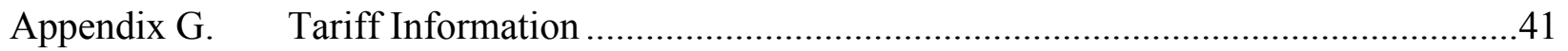

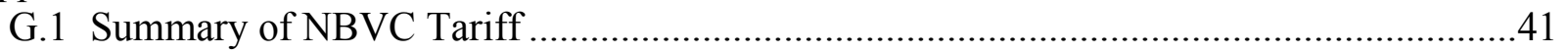

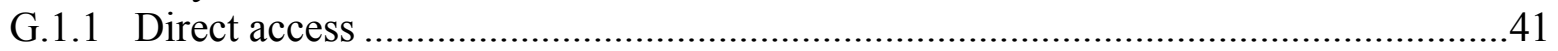

Other direct access tariff characteristics ..................................................................... 43

G.1.2 SCE TOU-8

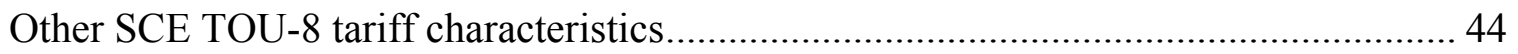

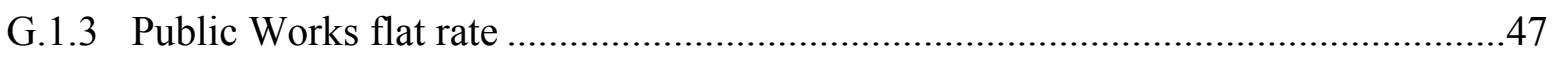

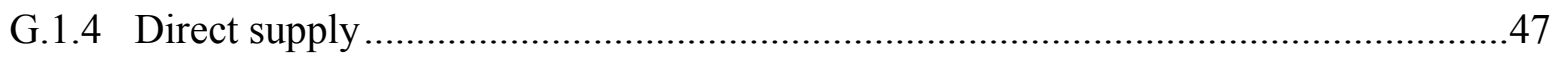




\section{List of Tables}

Table 1: Description of Scenarios Analyzed at NBVC ......................................................... 5

Table 2: Annual Building 1512 Energy Consumption and Production Results ........................... 9

Table 3: Annual Building 1512 Energy Cost Results ........................................................... 10

\section{List of Figures}

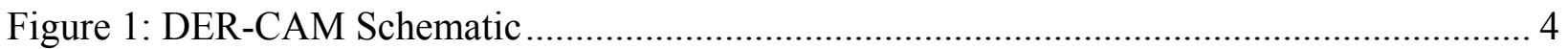

Figure 2: Summary of Results at Different Tariff Rates..................................................... 10 



\section{Appendix Tables}

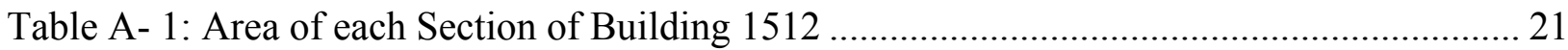

Table A- 2: DER-CAM Technology Cost and Performance Information...................................... 29

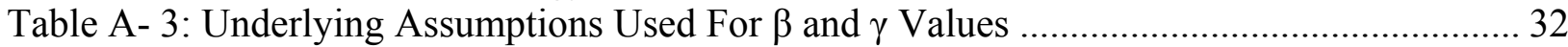

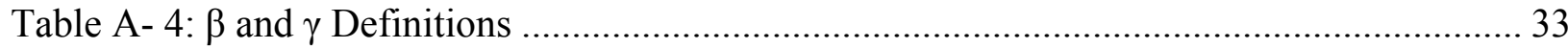

Table A- 5: Technologies Eligible for CPUC Self-Generation Rebates........................................ 35

Table A- 6: Direct Access Tariff Components at NBVC ………………..................................... 42

Table A- 7: SCE TOU-8 Tariff............................................................................................... 44

Table A- 8: SCE Schedule TOU-8, applicable for direct access and SCE TOU-8 tariffs ............ 45

Table A- 9: NBVC Public Works Tariff Charges for Port Hueneme Buildings ............................ 47

\section{Appendix Figures}

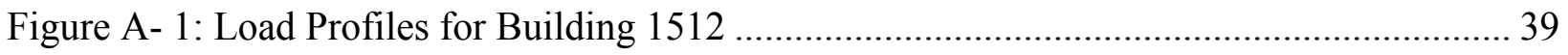

Figure A- 2: Direct Access Energy Supply Prices by Strategic Energy …………...................... 42

Figure A- 3: NBVC Natural Gas Commodity Prices 2002-2003 …............................................. 48 



\section{Acronyms and Abbreviations}

$\begin{array}{ll}\text { Abs } & \text { absorption cooling } \\ \text { CBC } & \text { Construction Battalion Center } \\ \text { CHP } & \text { combined heat and power } \\ \text { COP } & \text { coefficient of performance } \\ \text { CPUC } & \text { California Public Utilities Commission } \\ \text { DA } & \text { direct access } \\ \text { DA-CRS } & \text { direct access cost responsibility surcharge } \\ \text { DER-CAM } & \text { Distributed Energy Resources Customer Adoption Model } \\ \text { DG } & \text { distributed generation } \\ \text { DOE-2 } & \text { building energy simulation software developed by Berkeley Lab } \\ \text { DWR } & \text { Department of Water Resources } \\ \text { ESP } & \text { energy service provider } \\ \text { FEMP } & \text { Federal Energy Management Program } \\ \text { FERC } & \text { Federal Energy Regulatory Commission } \\ \text { GJ } & \text { gigajoule } \\ \text { HPC } & \text { historic procurement charge } \\ \text { KWh } & \text { kilowatt hour } \\ \text { MBTU } & \text { million BTU } \\ \text { MWh } & \text { megawatt hour } \\ \text { NAS } & \text { Naval Air Station } \\ \text { NBVC } & \text { the Naval Base Ventura County } \\ \text { NEX } & \text { Navy Exchange } \\ \text { NG } & \text { natural gas } \\ \text { NPV } & \text { net present value } \\ \text { NREL } & \text { National Renewable Energy Laboratory } \\ \text { O\&M } & \text { operation and maintenance } \\ \text { PV } & \text { photovoltaic } \\ \text { SCE } & \text { Southern California Edison } \\ \text { SI } & \text { Système International d'unités or International System of Units } \\ \text { SoCalGas } & \text { Southern California Gas Company } \\ \text { t/a } & \text { metric tons per year } \\ \text { TeChars } & \text { Technology Characterizations Report } \\ \text { TOU-8 } & \text { SCE time of use tariff number } 8 \\ \text { UPS } & \text { uninterruptible power supply } \\ \text { URG } & \text { utility retained generation } \\ & \end{array}$





\section{Executive Summary}

This paper reports the findings of a preliminary assessment of the cost effectiveness of distributed energy resources at Naval Base Ventura County (NBVC) Building 1512. This study was conducted in response to the base's request for design assistance to the Federal Energy Management Program.

Given the current tariff structure there are two main decisions facing NBVC: whether to install distributed energy resources (DER), or whether to continue the direct access energy supply contract. Each of these decisions would be made at different levels, involving different decision makers: at the building level for a DER system or at the base level for continuing the direct access contract.

This analysis focuses on the potential for energy savings in Building 1512 as the result of either installing a DER system or changing the tariff structure. Building 1512 is the largest electricity consumer on NBVC, but the estimated cost of its energy varies considerably depending on which of three possible electricity tariffs is applied. Monthly bill data and DOE-2 simulation were used to estimate building energy use profiles.

At the current effective rate, given assumptions about the performance and structure of building energy loads and available generating technology characteristics, the results of this study indicate that if the building installed a $600 \mathrm{~kW}$ DER system with absorption cooling and heat capabilities chosen by cost minimization, the energy cost savings would be about $14 \%$, or $\$ 55,000$ per year. However, under current conditions, this study also suggests that significant savings could be obtained if Building 1512 changed from the direct access contract to a SCE TOU-8 (Southern California Edison time of use tariff number 8) rate without installing a DER system. At current SCE TOU-8 tariffs, the potential savings from installation of a DER system would be about $4 \%$, or $\$ 15,000$ per year.

The magnitude of these savings is heavily influenced by both the structure of the electricity tariff and the ability to utilize residual heat from thermal DER technologies adequately. The tariff structure, especially the timing and level of billed rates for energy and power, greatly effects how a DER system is optimally operated. Installing natural gas fueled DER would substantially reduce electricity purchases from the grid to between 300 and 1,400 MWh annually depending upon the tariff. All DER installation options also offer substantial efficiency improvements of up to $65 \%$, and carbon emission reductions in the range of $20 \%$ or over $100 \mathrm{t} / \mathrm{a}$ (metric tons per annum).

A rate structure or commodity price change could easily change the annual energy bill by $\$ 50,000$ annually, roughly the difference in annual energy costs between Building 1512's electricity bill on its current direct access contract versus the default SCE TOU-8 rate. Further sensitivity analysis is recommended to understand the affects of energy prices and tariff structures on energy bills. 
Other factors, such as reliability or the ability to delay base distribution infrastructure investments, may drive the decision to install DER. Public Works staff and Building 1512 managers may want to explore the option of putting some of the building loads on critical load circuits backed up by a DER system, even though the base is a non-curtailable customer. Another option to consider is creating a microgrid, combining Building 1512 and nearby buildings with heat loads, possibly including the swimming pool and laundromat.

This study indicates that letting the current direct access tariff rate expire in March 2005 and switching the base's tariff to SCE TOU-8 may lead to financial savings for Building 1512 . However, if NBVC does not renew its direct access contract, the CPUC (California Public Utilities Commission) would not allow it to reenroll in the direct access contract if the TOU-8 rates later increase. Each decision carries risk. In the case of the DER system there is risk that the installation and operation and maintenance costs may be higher than expected, or that the availability, reliability, power quality, and thermal benefits may be lower than expected. Sensitivity analyses on DER cost parameter estimates can provide insight into the robustness of financial savings from a DER system at Building 1512.

A critical analysis is needed. A percentage savings on approximately $\$ 500,000$ per month electricity bills for Port Hueneme alone could be a substantial amount. 


\section{Introduction}

\subsection{Background}

This report details the results of a preliminary assessment of the cost effectiveness of distributed energy resources (DER) at Naval Base Ventura County (NBVC) Building 1512, and was prepared in response to a request by NBVC for design assistance to the Federal Energy Management Program (FEMP).

NBVC is comprised of two nearby bases located $100 \mathrm{~km}$ (60 miles) northwest of Los Angeles: the Naval Air Station (NAS) at Point Mugu and the Construction Battalion Center (CBC) at Port Hueneme, founded in 1941 and 1942 respectively. NBVC employs over 6,000 civilians, 9,000 military personnel and 1,300 contractor staff. In addition, NBVC hosts over 60 tenant commands. Point Mugu is home to NAS and has two runways; Port Hueneme is home of the $\mathrm{CBC}$ and a deep-water naval port.

Port Hueneme's Building 1512 was selected for the study because it has the largest electrical use on the two bases and is relatively easily accessed. It also offers opportunities for absorption cooling and is near other buildings with substantial thermal loads, which may ultimately become part of a broader microgrid. A microturbine is being installed to help heat the swimming pool at nearby Building 73.

\subsection{Description of Site}

Building 1512, with approximately $13,000 \mathrm{~m}^{2}\left(136,000 \mathrm{ft}^{2}\right)$ of floor space, houses the Navy Exchange or NEX (a large retail store), the Commissary (a large supermarket), and other smaller businesses, notably a food court. Building 1512 is the largest metered electricity consumer at either Port Hueneme or Point Mugu.

The Naval Base purchases electricity from Strategic Energy LLC, and retail and delivery services from Southern California Edison (SCE) under a legacy (effective prior to September 2001) energy service provider (ESP) contract. Natural gas is procured through the Defense Energy Support Center in Fort Belvoir, VA and delivered by Southern California Gas (SoCalGas). NBVC Public Works Department recharges base facilities at fixed prices for electricity, natural gas, and water based on metered consumption.

\subsection{Ongoing Energy Activity at NBVC}

Port Hueneme has several ongoing energy projects and demonstrations. C\&H Engineering performed a standby generator optimization review under subcontract to SoCalGas. ${ }^{1}$ The Public Works building is powered by a $31 \mathrm{~kW}$ rooftop photovoltaic (PV) system, which serves all power requirements for the building and acts as an uninterruptible power supply (UPS). ${ }^{2}$ On

\footnotetext{
${ }^{1}$ Naval Base Ventura County Standby Generator Optimization Review, Southern California Gas Company, August 2001.

${ }^{2}$ Tom Santoianni, personal communication.
} 
sunny days, the PV supplies power into the base's electricity network. ${ }^{3}$ There are also four solar thermal collectors supplying the building's hot water requirements.

\footnotetext{
${ }^{3}$ Tom Santoianni, email communication, 25 March 2004.
} 


\section{Method}

\subsection{Site Selection Process}

Building 1512 was selected after a site visit because it has the largest electrical load on the two bases, presents interesting opportunities for absorption cooling, and is near several buildings that may together eventually become a microgrid. The building is approximately $13,000 \mathrm{~m}^{2}(136,000$ $\mathrm{ft}^{2}$ ). In fiscal year 2003 it consumed 2,904 MWh of electricity and 1,239 GJ (1,174 MBTU) of natural gas. ${ }^{4}$ The peak electrical load is estimated to be around $1200 \mathrm{~kW}$. The presence of both retail and grocery stores make Building 1512 central to personal life at the base. The surrounding buildings also have energy loads potentially interesting for future microgrid analyses, e.g. a gas station, a McDonald's, a laundromat, a bowling alley, a large outdoor pool with locker rooms, and a gymnasium.

\subsection{DER-CAM Overview}

The Distributed Energy Resources Customer Adoption Model (DER-CAM) was used for part of the analysis of Building 1512. The program finds the optimal combination of installed equipment along with an idealized operating schedule to minimize the site's energy bills, given performance and cost data on available DER technologies, utility tariffs, and site electrical and thermal loads over an historic test period.

DER-CAM is a mixed integer program formulated in GAMS (General Algebraic Modeling System $)^{5}$. The objective function it minimizes is the annual cost of providing energy services to the site, through either utility electricity and gas purchases or DER operation (or a combination of both) in total dollars for a test year, typically a recent historic year. The objective function estimates the annual costs of electricity purchases, gas purchases (for direct use and as generating fuel), operating and maintenance (O\&M) costs, and the annualized capital costs of DER equipment.

The program output is an idealized set of DER technologies to install (if feasible) to meet the five energy end uses: electricity-only, cooling, space heating, water heating, and natural-gasonly. Output includes hourly operating schedules as well as utility electricity and natural gas purchases, all selected to minimize the annual costs of meeting energy demand for the site over the test year.

A key constraint is that each hour's energy demand must be met in one of three ways: purchase of energy from utilities, operation of a technology or set of technologies selected by the model, or a combination of these options. In addition, all environmental rules must be obeyed, and technical equipment capabilities must not be exceeded.

Another key performance constraint is that any installed DER technologies must operate at 50\% or more of their nameplate capacity or they will be shut down (with the exception of PV

\footnotetext{
${ }^{4}$ NBVC Public Works. "Top Utility Consumers for FY 03.” Received December 2003.

${ }^{5}$ GAMS is a proprietary software product used for high-level modeling of mathematical programming problems. It is owned by the GAMS Development Corporation (http://www.gams.com) and is licensed to Berkeley Lab.
} 
technologies). This constraint ensures that the generators operate in their most efficient power range and that multiple generators are installed to meet fluctuating energy loads.

The model's inputs and outputs are depicted graphically in Figure 1 below.

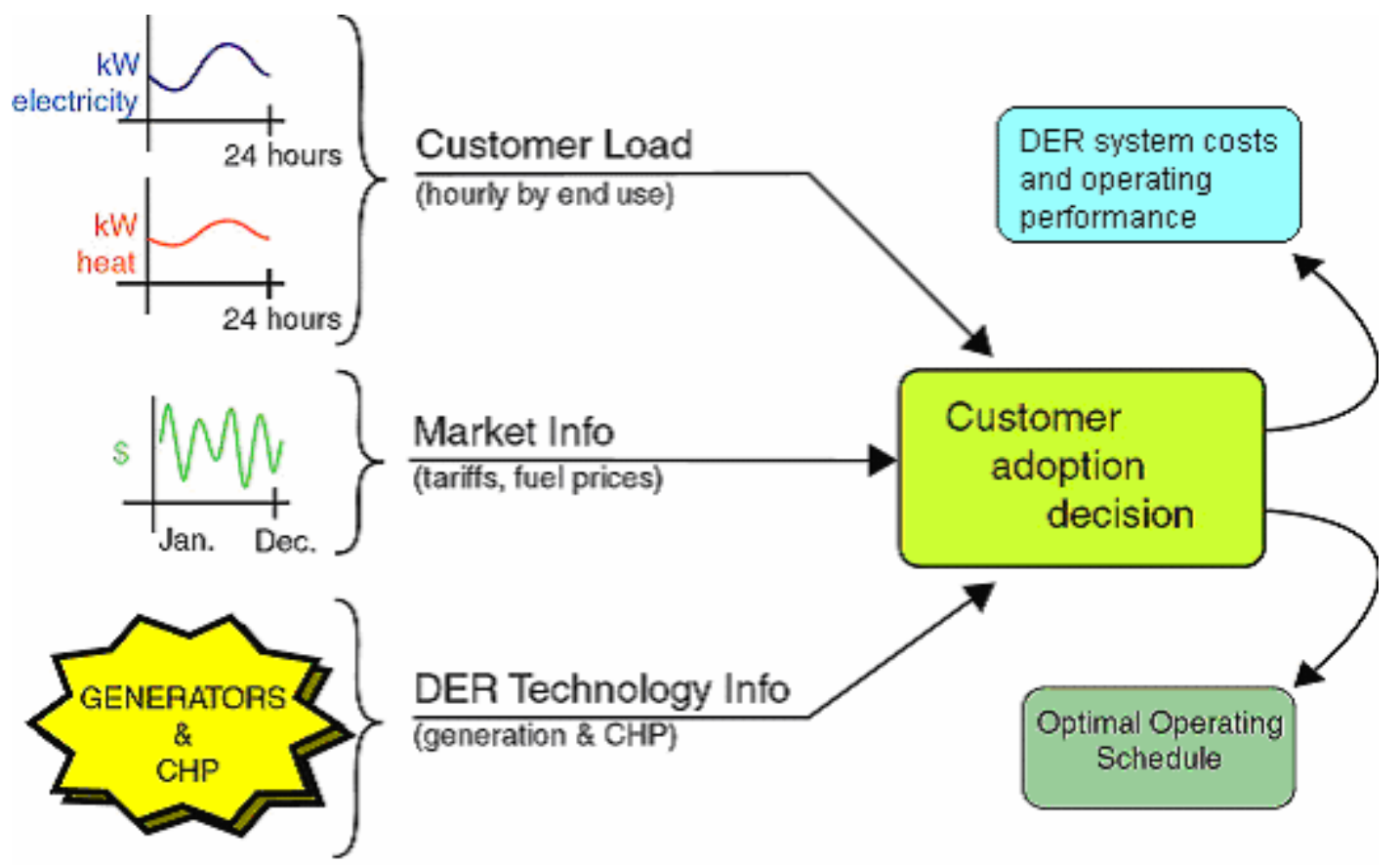

\section{Figure 1: DER-CAM Schematic}

DER-CAM results are not intended as fully documented proposals for DER systems. Rather they are meant to deliver insight into the general technologies and system configurations worthy of further analysis.

\subsection{Operating Scenarios}

Table 1 summarizes two scenarios modeled to explore the potential options available for DER installation. Both provide useful information for determining the financial benefits of different DER system designs, and each was modeled under the three different tariffs, the Public Works flat recharge rate, the default SCE TOU-8 tariff, and the actual effective direct access contract rate. Notice also that the cases using the flat recharge rate also use the flat natural gas rate while the other cases use a direct access gas rate. The "no DER installation" scenario provides the baseline for determining any financial benefits of DER systems, and the "installation of DER" scenario is the actual optimization in which the model may select any combination of DER technologies and operating schedules. 
Table 1: Description of Scenarios Analyzed at NBVC

\begin{tabular}{|l|l|l|l|}
\hline Scenario & Case Name & Electricity Tariff & Natural Gas Tariff \\
\hline $\begin{array}{l}\text { Scenario 1 } \\
\text { No DER } \\
\text { installation }\end{array}$ & No DER Flat Rate & $\begin{array}{l}\text { Public Works flat } \\
\text { recharge rate }\end{array}$ & $\begin{array}{l}\text { Public Works flat } \\
\text { recharge rate }\end{array}$ \\
\cline { 2 - 4 } & No DER SCE TOU-8 & SCE TOU-8 tariff & direct access \\
\cline { 2 - 4 } & $\begin{array}{l}\text { No DER } \\
\text { direct access }\end{array}$ & $\begin{array}{l}\text { direct access: } \\
\text { current legacy } \\
\text { contract }\end{array}$ & direct access \\
\hline $\begin{array}{l}\text { Scenario 2 } \\
\text { Installation of }\end{array}$ & DER \\
$\begin{array}{l}\text { Any technology } \\
\text { and capacity } \\
\text { combination } \\
\text { allowed (true } \\
\text { optimization). }\end{array}$ & DER & $\begin{array}{l}\text { Public Works flat } \\
\text { recharge rate }\end{array}$ & $\begin{array}{l}\text { Public Works flat } \\
\text { recharge rate }\end{array}$ \\
\cline { 2 - 4 } & DER direct access & SCE TOU-8 tariff & direct access \\
\hline
\end{tabular}

\subsection{Load Profiles}

The tariff situation at NBVC is complex, as described below, and a major effort was required to unravel it. Ideally, complete electric and thermal load profiles based on hourly measurements for a full year (historical, or even better, forecast) would be available as inputs to DER-CAM. At NBVC, however, hourly and peak load data, or other load shape information was not available. Deborah Stewart, Public Utilities Specialist, provided a spreadsheet of monthly meter readings for both the Commissary and the NEX for last five years (November 1998 to January 2004) showing energy consumption since the previous meter reading in MWh and MBTU. These electric and natural gas meter data were averaged to obtain baseline monthly consumption.

The DOE-2 building energy simulator was used to develop hourly electricity, heating, and cooling loads, which were otherwise unavailable. The following building types were used to approximate Building 1512: a retail store (NEX), a supermarket (Commissary), and a fast food restaurant (the food court).

The five DER-CAM load types used in this study are:

- electric-only: loads met only by electricity that cannot be met by natural gas or CHP (combined heat and power), such as lighting, and computing,

- space cooling: loads met by electricity or heat recovery through absorption chillers,

- space heating: loads met either directly by natural gas or with residual heat from CHP,

- water heating: loads met either directly by natural gas or with residual heat from CHP,

- natural-gas-only: loads met only by natural gas and not CHP opportunities (primarily cooking).

The outputs were added to total the loads for each major component of Building 1512 and then adjusted to match the historic metered data (from November 1998 to January 2004). Electric- 
only and cooling loads from DOE-2 were multiplied by a factor of 0.96 to calibrate them to the average loads provided by historic meter readings. The space heating, water heating, and natural-gas-only loads from DOE-2 were multiplied by 0.85 . The test site load profiles described in this report are presented in Appendix F.

\section{$2.5 \quad$ Tariffs}

\subsubsection{Direct access}

NBVC has a direct access contract with an energy service provider, Strategic Energy, and electricity delivery services through SCE under tariff TOU-8 Direct Access. The Strategic Energy contract is effective through March 2005 and renewable indefinitely. ${ }^{6}$ Natural gas is also purchased from a direct supplier, with SoCalGas charging for delivery. The net tariff estimated by combining the Strategic Energy charge and the SCE TOU-8 direct access charge is here called the "direct access" tariff.

\subsubsection{SCE TOU-8}

The SCE tariff that would be effective if the base had not entered into the direct access agreement before September 20, 2001 is called the SCE TOU-8 tariff. It is the same rate available for large customers obtaining electric service over $50 \mathrm{kV}$.

\subsubsection{Public Works flat rate}

The Public Works Department of NBVC recharges each building a flat rate for electricity and gas that is quite different from the direct access tariff. Port Hueneme and Point Mugu each charge all buildings at that base a unique rate. Building 1512 at Port Hueneme is billed a flat rate of \$133.49/MWh for electricity and \$7.12 GJ (\$7.51/MBTU) for natural gas.

\subsubsection{Direct supply}

Natural gas is obtained through the Defense Energy Support Center in Fort Belvoir, VA. Prices from August 2003 to September 2002 fluctuated between \$3.16/ GJ and \$6.63/GJ (\$3.330/MBTU and \$6.99/MBTU), so an average price of $\$ 5.11 / \mathrm{GJ}(\$ 5.39 / \mathrm{MBTU})$ was used. SoCalGas delivers the gas at a variable monthly rate, which was set at $\$ 0.95 / \mathrm{GJ}(\$ 1.00 / \mathrm{MBTU})$ based on the historic average. The total direct access gas rate is $\$ 6.06 / \mathrm{GJ}$ ( $\$ 6.39 / \mathrm{MBTU})$.

\subsection{DER Technology Information}

The technologies in the DER-CAM database include gas turbines, microturbines, natural gas engines, photovoltaics, and fuel cells. Each DER technology has three versions describing different CHP configurations with resulting outputs: electricity only; electricity and heat; and electricity, heat, and cooling. To be consistent across technologies, DER capital costs and performance specifications are primarily taken from the Technology Characterization Report (TeChars) (Goldstein et al., 2003). For this project, SelfGen grants from the CPUC, the

\footnotetext{
${ }^{6}$ Veronica Jarvis, Strategic Energy, personal communication, March 2004.
} 
statewide self-generation incentive program, were then factored in and reduce the capital cost of applicable technologies. A more detailed description of the technologies is presented in Appendix D, where Table A- 2 describes the technology cost and performance information used in DER-CAM.

DER technologies (other than PV) must operate at $50 \%$ or more of their nameplate (maximum) power rating or be shut down. Manufacturers specify these ratings at maximum power output but they tend to decline substantially at lower load levels. This ensures that the generator's heat rate and fuel efficiency are more realistic to actual conditions. 



\section{Results of NBVC Analysis}

\subsection{Results}

Annual energy balance results for each scenario are presented below in Table 2, and the cost results in Table 3. Note that in Table 2 the value for absorption cooling is the displaced electrical load in MWh. Space and water heating thermal loads are met with residual heat from DER.

Table 2: Annual Building 1512 Energy Consumption and Production Results

\begin{tabular}{|c|c|c|c|c|c|c|c|c|c|c|}
\hline CASE & $\begin{array}{l}\mathrm{Ca} \\
\mathrm{pa} \\
\mathrm{cit} \\
\mathrm{y} \\
\text { Ins } \\
\text { tall } \\
\mathrm{ed}\end{array}$ & $\begin{array}{c}\% \\
\text { of } \\
\text { Pe } \\
\text { ak } \\
\text { Lo } \\
\text { ad } \\
\end{array}$ & Equipment & $\begin{array}{l}\text { sy } \\
\text { ste } \\
\text { m } \\
\text { Eff } \\
\text { ici } \\
\text { en } \\
\text { cv }\end{array}$ & \multicolumn{3}{|c|}{ Annual Utility Purchase } & \multicolumn{3}{|c|}{ Annual DER Production } \\
\hline & & & & & Electricity & Gas & Gas & \begin{tabular}{|c|}
$\begin{array}{c}\text { Electricity } \\
\text { loads }\end{array}$ \\
\end{tabular} & Abs. Cool & $\begin{array}{c}\text { Thermal } \\
\text { loads }\end{array}$ \\
\hline & $(\mathrm{kW})$ & & & & (MWh) & $\begin{array}{c}\text { for DER } \\
(\mathrm{MWh})\end{array}$ & $\begin{array}{c}\text { for direct } \\
\text { end use } \\
\text { (MWh) }\end{array}$ & (MWh) & (MWh) & (MWh) \\
\hline $\begin{array}{l}\text { No DER flat } \\
\text { rate }\end{array}$ & & & & $35 \%$ & 3,553 & 0 & 426 & 0 & 0 & 0 \\
\hline $\begin{array}{l}\text { No DER SCE } \\
\text { TOU-8 }\end{array}$ & & & & $35 \%$ & 3,553 & 0 & 426 & 0 & 0 & 0 \\
\hline $\begin{array}{l}\text { No DER direct } \\
\text { access }\end{array}$ & & & & $35 \%$ & 3,553 & 0 & 426 & 0 & 0 & 0 \\
\hline DER flat rate & 700 & $58 \%$ & $\begin{array}{l}300 \text { kW NG eng. } \\
\text { abs.cooling, } 100 \\
\text { kW NG eng. CHP, } \\
300 \text { kW PV }\end{array}$ & $73 \%$ & 164 & 7,164 & 79 & 3,113 & 276 & 347 \\
\hline $\begin{array}{l}\text { DER SCE } \\
\text { TOU-8 }\end{array}$ & 600 & $50 \%$ & $\begin{array}{l}2 \times 300 \mathrm{~kW} \mathrm{NG} \\
\text { engine with } \\
\text { absorption cooling }\end{array}$ & $61 \%$ & 1,392 & 5,784 & 140 & 1,793 & 368 & 286 \\
\hline $\begin{array}{l}\text { DER direct } \\
\text { access }\end{array}$ & 600 & $50 \%$ & $\begin{array}{l}2 \times 300 \mathrm{~kW} \mathrm{NG} \\
\text { engine with } \\
\text { absorption cooling }\end{array}$ & $67 \%$ & 303 & 9,034 & 85 & 2,801 & 450 & 342 \\
\hline
\end{tabular}

Note: $1 \mathrm{MWh}=3,600 \mathrm{MJ}=34.13$ therms $=3,412,141 \mathrm{BTU}$ 
Table 3: Annual Building 1512 Energy Cost Results

\begin{tabular}{|c|c|c|c|c|c|c|c|c|c|c|c|}
\hline CASE & $\begin{array}{l}\text { pad } \\
\text { ity } \\
\text { Ins } \\
\text { alle } \\
d\end{array}$ & Equipment & $\begin{array}{l}\text { est } \\
\text { me } \\
\text { nt } \\
\text { Co } \\
\text { sts }(\mathrm{k} \$ \\
\quad / a)\end{array}$ & \begin{tabular}{l} 
O\& \\
M \\
Var \\
iabl \\
e Co \\
\multicolumn{1}{c}{ st } \\
\end{tabular} & \multicolumn{3}{|c|}{ Annual Utility Bills } & \multirow{2}{*}{$\begin{array}{c}\text { Total } \\
\text { Energy } \\
\text { Costs } \\
\end{array}$} & \multirow{2}{*}{$\begin{array}{l}\text { Ave. } \\
\text { Elec. } \\
\text { Price }\end{array}$} & \multirow{2}{*}{$\begin{array}{l}\text { Bill Savings } \\
\text { Over No } \\
\text { DER Case }\end{array}$} & \multirow{2}{*}{$\begin{array}{c}\text { Carbon } \\
\text { Emissions }\end{array}$} \\
\hline & & & & & Electricity & Gas & Gas & & & & \\
\hline & $(\mathrm{kW})$ & & $(\mathrm{k} \$)$ & $(\mathrm{k} \$)$ & $(\mathrm{k} \$)$ & $\begin{array}{c}\text { for DER } \\
(\mathrm{k} \$)\end{array}$ & $\begin{array}{c}\text { for direct } \\
\text { end use } \\
(\mathrm{k} \$)\end{array}$ & $(\mathrm{k} \$)$ & $\$ / \mathrm{kWh}$ & $(\%)$ & $\mathrm{t} / \mathrm{a}$ \\
\hline $\begin{array}{l}\text { No DER flat } \\
\text { rate }\end{array}$ & & & 0 & 0 & 474 & 0 & 13 & 487 & 0.1335 & & 612 \\
\hline $\begin{array}{l}\text { No DER SCE } \\
\text { TOU-8 } \\
\end{array}$ & & & 0 & 0 & 340 & 0 & 15 & 355 & 0.0956 & & 612 \\
\hline $\begin{array}{l}\text { No DER direct } \\
\text { access }\end{array}$ & & & 0 & 0 & 390 & 0 & 15 & 405 & 0.1097 & & 612 \\
\hline DER flat rate & 700 & $\begin{array}{l}300 \text { kW NG eng. } \\
\text { abs.cooling, } 100 \\
\text { kW NG eng. CHP, } \\
300 \text { kW PV }\end{array}$ & 116 & 43 & 22 & 184 & 2 & 366 & 0.1025 & $25 \%$ & 376 \\
\hline $\begin{array}{l}\text { DER SCE } \\
\text { TOU-8 }\end{array}$ & 600 & $\begin{array}{l}2 \times 300 \mathrm{~kW} \text { NG } \\
\text { engine with } \\
\text { absorption cooling }\end{array}$ & 64 & 30 & 112 & 126 & 8 & 340 & 0.0935 & $4 \%$ & 516 \\
\hline $\begin{array}{l}\text { DER direct } \\
\text { access }\end{array}$ & 600 & $\begin{array}{l}2 \times 300 \mathrm{~kW} \text { NG } \\
\text { engine with } \\
\text { absorption cooling }\end{array}$ & 60 & 47 & 40 & 197 & 6 & 350 & 0.0969 & $14 \%$ & 489 \\
\hline
\end{tabular}

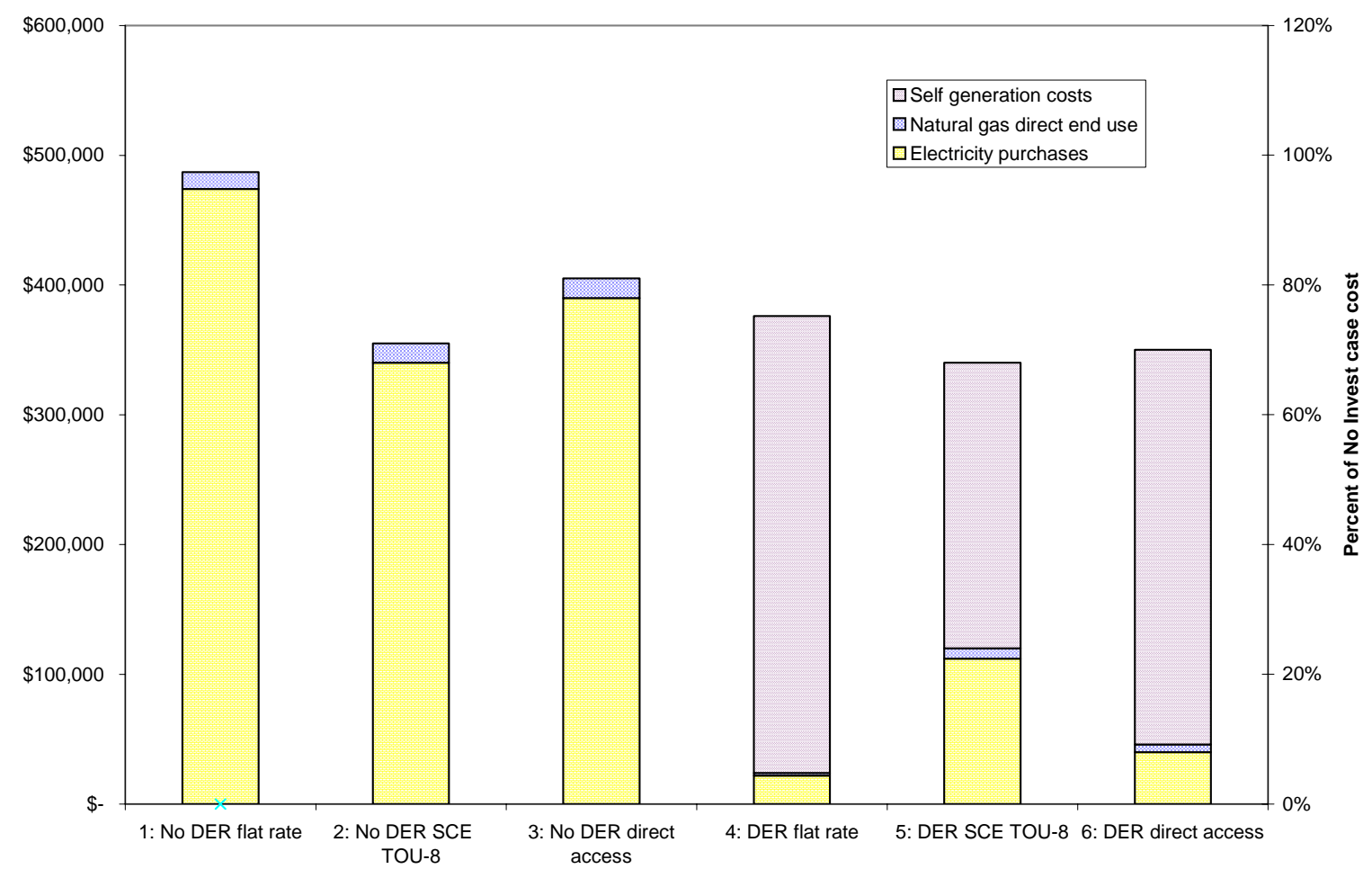

Figure 2: Summary of Results at Different Tariff Rates 


\section{Discussion of Results}

\subsection{Scenario 1 Results: No DER Installation}

Scenario 1 models the options available without investing in DER.

The No DER flat rate and DER flat rate cases use the internal natural gas price recharged by the base. However, since monthly electricity consumption is about ten times that of natural gas on a $\mathrm{kWh}$ basis, variation in the natural gas price does not greatly influence results. In fact, natural gas expenses are just 3-5\% of the total energy expenditures. Each of the three cases has an efficiency of $35 \%$.

The average electricity price is calculated by dividing costs incurred in purchasing or producing electricity by the total electricity consumption, 3,553 MWh per year. These electricity costs include the investment, operation and maintenance, and fuel costs of the DG (distributed generation) equipment, along with the cost of purchasing utility electricity including demand charges.

\subsubsection{No DER flat rate}

The No DER flat rate has higher energy prices for both electricity and gas, but no demand or other monthly service charges. The average electricity price is $\$ 0.1335$. The total annual bill is $\$ 487,000$ for both electricity and natural gas, over a $20 \%$ markup or $\$ 82,000$ per year over the bill actually paid by the base. On the other hand, natural gas expenses of $\$ 13,000$ are lower than the $\$ 15,000$ that would be due under the DA tariff because the price increase is offset by the absence of the $\$ 350$ per month customer charge. Carbon emissions of $612 \mathrm{t} / \mathrm{a}$ are the same for all of Scenario 1 cases because energy use remains constant.

\subsubsection{No DER SCE TOU-8}

If NBVC had not contracted with an energy service provider and were purchasing electricity under the default SCE tariff, total energy bills for Building 1512 would be $12 \%$ lower. This difference in cost, $\$ 405,000$ versus $\$ 355,000$, appears to be mostly due to the difference in energy charges. SCE TOU-8 prices per $\mathrm{kWh}$ are typically $25 \%-40 \%$ lower than direct access energy prices, although the summer on-peak price for SCE TOU-8 is about $20 \%$ higher than the direct access summer on-peak price. The average kWh price for the No DER SCE TOU-8 case is $\$ 0.0956 / \mathrm{kWh}$ or about $\$ 0.014$ per $\mathrm{kWh}$ lower than the $\$ 0.1097 / \mathrm{kWh}$ average price of the No DER direct access tariff. The demand charges for SCE TOU- 8 are about twice as expensive as those for the direct access tariff, or $\$ 78,000$ per year verses $\$ 41,000$ per year. The energy charges of SCE TOU-8 tariff are $\$ 262,000$ compared to $\$ 349,000$ for the direct access tariff. These energy costs result in the SCE TOU- 8 tariff being $\$ 50,000$ per year less expensive than the direct access tariff for Building 1512.

\subsubsection{No DER direct access}

In the No DER direct access case the total annual energy bill is $\$ 405,000$ with $\$ 390,000$ for electricity and $\$ 15,000$ for natural gas. The average price of electricity is $\$ 0.1097$. This tariff 
has lower demand charges (summer on-peak $\mathrm{kW}$ is $\$ 6.91 / \mathrm{kW}$ for direct access as opposed to $\$ 15.01 / \mathrm{kW}$ for SCE TOU-8) and a flat energy rate. As noted above, the higher energy charge is the main contributor to the higher annual energy bill for the No DER direct access case compared to the No DER SCE TOU-8 case.

\subsection{Scenario 2 Results: Installation of DER}

Scenario 2 models the option to invest in DER at Building 1512 under each of the three tariffs.

\subsubsection{DER flat rate}

Given the opportunity to invest in a DER system under the flat rate tariff structure, DER-CAM gives an optimal result of $700 \mathrm{~kW}$ installed capacity comprised of one $300 \mathrm{~kW}$ natural gas engine with absorption cooling and heat recovery capabilities, a second $100 \mathrm{~kW}$ natural gas engine with heat recovery, and $300 \mathrm{~kW}$ of PV. The system efficiency is a high $73 \%$ due to the CHP and PV energy where sunlight is considered free (i.e. not included in the efficiency calculation). The efficiency when calculated using the FERC method (giving $1 / 2$ credit for the residual heat production) is $60 \%$, or well beyond the $42.5 \%$ needed to qualify for the CPUC SelfGen grants. This scenario has an installed capital cost of about $\$ 1,600,000$, annualized to $\$ 116,000$ per year over the lifetime of the equipment (30 years for PV and 20 years for the natural gas engines) at a $5 \%$ real interest rate. The operating costs are $\$ 43,000$, which reflect the large amount of on-site energy generation and high capacity factor for the natural gas engine. O\&M variable costs are increased by $\$ 0.00382 / \mathrm{kWh}$ to account for the SCE departing load charge (a $40 \%$ increase for natural gas engines).

The DER system reduces electricity purchases to just $\$ 22,000$ per year, down from $\$ 474,000$ in No DER flat rate case. Natural gas consumption, however, increases from $\$ 13,000$ to $\$ 186,000$ to fuel the engines, although residual heat displaces some gas use. The total energy costs are $\$ 366,000$ per year; the DER system installed reduces energy expenses by $25 \%$ compared to No DER flat rate. The average cost of electricity is $\$ 0.1025 / \mathrm{kWh}$. This case results in the lowest carbon emissions of all the scenarios at $376 \mathrm{t} / \mathrm{a}$, a reduction of nearly $40 \%$. This is due to the higher operating hours of the DER system, the use of residual heat to serve cooling and heating loads at the site, and the installation of a PV system. The DER equipment produces $3.1 \mathrm{GWh}$ over the year for a capacity factor of $51 \%$. The capacity factor of the natural gas engines and the PV system individually is $63 \%$ and $34 \%$ respectively. PV produces $30 \%$ of electricity generated on site.

\subsubsection{DER SCE TOU-8}

The results of the DER SCE TOU-8 case include $600 \mathrm{~kW}$ installed capacity including two 300 $\mathrm{kW}$ natural gas engines with absorption cooling and CHP capabilities. The system efficiency would be $61 \%$ due to the use of residual heat in the absorption chiller and CHP system; the FERC efficiency is $56 \%$. The installed capital cost is $\$ 620,000$, or $\$ 64,000$ per year annualized over the lifetime of the equipment. The annual O\&M variable costs are $\$ 30,000$ per year, including the departing load charge on all $\mathrm{kWh}$ generated on site. The annual out-of-pocket electricity bill is $\$ 112,000$. Gas bills for the DER system are $\$ 126,000$, the lowest of all the investment cases due to the low capacity factor (34\%) on the natural gas engines. Total energy 
bills result in a savings of $4 \%$ and a $16 \%$ drop in carbon emissions when compared to No DER SCE TOU-8. Note that although the results of the DER SCE TOU-8 case indicate slightly decreased energy costs $(\$ 10,000$ per year) compared to the DER direct access case, the carbon emissions are $6 \%$ higher because of increased electricity purchases from the grid (composed of mixed coal and natural gas generation), and reduced use of residual heat for heating and cooling loads. This DER system produces $1.8 \mathrm{GWh}$ per year.

\subsubsection{DER direct access}

The DER direct access case reduces annual energy bills by $\$ 55,000$ (about $14 \%$ ) to $\$ 350,000$ compared to the No DER direct access case. The optimal installed capacity for this case is 600 $\mathrm{kW}$ from two $300 \mathrm{~kW}$ natural gas engines, with absorption cooling and heat production for thermal loads supplying about $50 \%$ of the building's peak load. The savings are driven by a reduction in gas for thermal load use and also by the use of absorption cooling. The installed capital cost is $\$ 620,000$, or $\$ 60,000$ per year over the lifetime of the equipment. The annualized capital cost is $\$ 4,000$ lower than in the DER SCE TOU-8 case because of lower standby charges. O\&M variable costs are $\$ 47,000$ per year. The annual electricity purchases total $\$ 40,000$ per year and the gas purchases for the DER system total $\$ 197,000$ per year. These suggest a higher DER system utilization than the DER SCE TOU-8 case and, indeed, the capacity factor is higher at $53 \%$. The average price for all the electricity purchased from the utility and generated on site is $\$ 0.0969 / \mathrm{kWh}$. The system efficiency is $67 \%$, the FERC efficiency is $50 \%$, and the carbon emissions are 489 t/a. The DER system produces $2.8 \mathrm{GWh}$ per year.

\subsubsection{Comments}

Given the current tariff structure, there are two main decisions facing NBVC: whether to install DER, or whether to continue the direct access energy supply contract. Each of these decisions would have to be made at different levels, perhaps involving different decision makers: at the building level for a DER system and at the base level for discontinuing the direct access contract.

Building 1512 may reduce its energy bills about $14 \%$ by installing a DER system. Savings of this magnitude could also be obtained if Building 1512 were to change from the direct access contract to SCE TOU-8. Installing DER would substantially reduce electricity purchases from the grid to between 300 and 1,400 MWh annually depending upon the tariff rate. The structure of the tariff rate, including the level of the energy and power charges, has a great effect on how a DER system is optimally operated. All the DER installation options offer substantial efficiency improvements and carbon emission reductions.

Each decision carries risk. In the case of the DER system there is risk that the installation and operation and maintenance costs may be higher than expected, or the availability, reliability, power quality, and thermal benefits may be lower than expected. In the case of not renewing the direct access contract, if SCE's TOU-8 rates increase in the future to the point where direct access is more favorable, it will not be possible to reenroll in the direct access contract due to a ruling by the CPUC. The current direct access contract expires in March 2005 and a critical analysis should be made to determine if this contract is worth continuing. A $10 \%$ savings on 
approximately $\$ 500,000$ per month electricity bills for Port Hueneme alone is a substantial amount.

These results show the interesting effects of DER adoption at three different tariff structures with regard to time of use energy and power charges. It is interesting that the case with a completely flat rate structure, the DER flat rate, has the most installed capacity and the most electricity generation (3.1 GWh per year), and the case with the highest peak time charges for energy and power, DER SCE TOU-8, has the lowest DER electricity generation and capacity utilization (1.8 GWh per year and 34\% respectively). This suggests the price of energy per kWh has a greater affect on DER capacity and operation than the daily and seasonal shape of the tariff structure 


\section{Areas of Further Study}

This report is a preliminary assessment of financial implications of possible DER system installation at Building 1512. Additional areas could be researched to improve understanding of the costs and benefits of a DER system and how various parameters may influence them. In addition to those previously mentioned, a number of other variables could also be considered in the sensitivity analysis including:

- outages,

- spark spread rate,

- technology cost and lifetime,

- technology heat rate (efficiency),

- demand and standby charge,

- interest rate, and

- changes to heat flow rate parameters (alpha, beta, and gamma).

A detailed financial analysis of the costs and benefits of any proposed system should be performed. Further study could examine the costs and benefits incurred from incorporating the reliability of generators into the model. This would provide information on the effect of DER outages on demand charges for example, or the benefit of having backup power for critical loads. In this type of analysis the loads would be randomized and the DER and utility power supply would fail at random times.

Another question to look into could be how well residual heat from DER and absorption chiller equipment could meet the refrigeration loads of both the Commissary and NEX. Additional research would need to be done to determine the feasibility, cost and performance of this technology for refrigerator cooling at Building 1512.

DER-CAM results involving the use of natural gas as supplementary heat for an absorption chiller is another area. This would allow the use of gas in combination with residual heat to serve cooling loads and may make absorption cooling more economically attractive.

This work could be expanded into a microgrid analysis including loads from surrounding buildings. Adjacent to Building 1512 are a fast food restaurant, gas station, laundromat, bowling alley, video rental store, outdoor swimming pool, gymnasium, and one-story office building. The swimming pool will soon have a microturbine providing electricity and heat to the facility and this unit could be modeled as part of the microgrid.

In the area of utility tariff and permits, further investigation could be made into the changes to SCE tariff that a departing load would initiate. Also the air quality permitting issue could be investigated.

Analysis of the feasibility of installing a PV system could be performed. This would study the amount of additional rebate, or the prices of electricity and gas, that might make PV cost effective. Preliminary analysis for the flat rate scenario shows that if gas prices increase by $10 \%$ 
over current Public Works levels, then PV might be cost effective. The resulting improvements in system efficiency and carbon emissions would be discussed.

A study could be performed to minimize the exposure to fuel price risk, specifically to find the technology installation and operating schedule that results in energy costs being evenly balanced between electricity and natural gas. 


\section{Conclusion}

This preliminary assessment of the cost effectiveness of distributed energy resources at Naval Base Ventura County (NBVC) Building 1512 indicates an opportunity for cost reductions from a DER system. There may be opportunities to improve the cost-effectiveness of DER by using the residual heat for serving refrigerator and freezer cooling loads in the Commissary and NEX. Financial savings may also be obtained for Building 1512 from switching to SCE TOU-8 rates by letting the current direct access contract expire.

Because electricity consumption at Building 1512 is so great, the results of the model are highly dependent on the electricity tariff and its structure. There are many parameters in the model, including demand charges, electricity and natural gas rates, technology capital cost and efficiencies, and energy demand profiles, which could be studied using sensitivity analysis to determine the affect each has on annual energy cost and technology installation and operation results.

At current tariff rates, and given assumptions about the building's energy loads and available technology performance, the results of the study indicate that savings of approximately $14 \%$ could be realized if the building installed DER. These savings may be increased by greater use of the residual heat in a DER system. The inability to use all the site's residual heat stems from the lack of heat loads in the building and the inability of the current version of DER-CAM to allow use of residual heat in refrigerator and freezer cooling applications. This could be improved by a more detailed engineering study on the capacities and estimated performance of the refrigerator and freezer cooling systems in the building. It is also possible to develop estimates of the cooling load potential and gather additional cost and performance data on absorption chilling systems and include that information into the model.

There are also numerous buildings near Building 1512 that have substantial heat or electricity loads. These include a laundromat, swimming pool facility, gymnasium, fast food restaurant, gas station, and office building.

There are many other opportunities for further study at NBVC. Finding the point where NBVC and Building 1512 are balancing exposure due to price changes in electric and natural gas prices equally would be useful if the building managers want to hedge against commodity price increases by installing a mid-size DER system. This analysis shows the energy consumption for the building switching between almost all electricity (as it is now) to almost all natural gas (under the SCE TOU-8 rate) with some DER installations.

A rate structure or commodity price change could easily affect the annual energy cost by $\$ 50,000$ or more. This is the difference between Building 1512's costs on the current direct access contract versus SCE's TOU-8 rates. DER is currently cost effective at direct access tariff rates, saving $\$ 50,000$ per year, but not significantly so at SCE TOU-8 rates. If the SCE electricity rates increase, either due to a change in generation or delivery prices, or percentage of generation served by Department of Water Resources (DWR) sources, then DER may become cost effective. (DWR generation tends to be more expensive than SCE's utility retained generation (URG) sources.) 
The decision to install DER may also be driven by other factors such as reliability or the ability to delay on-base distribution infrastructure investments. Building 1512 and the Public Works may want to explore the options of putting some of the building's loads on critical load circuits backed up by a DER system. 


\section{References}

Bailey, O. C. Creighton, R. Firestone, C. Marnay, and M. Stadler. February 2003. "Distributed Energy Resources in Practice: A Case Study Analysis and Validation of LBNL’s Customer Adoption Model. Berkeley Lab Report LBNL-52753.

CBC Meter Readings FY-03 and FY04. Provided by Deborah Stewart, Public Utilities Specialist, NBVC. December 2003 and March 2004.

Firestone, Ryan. January 2004. "Distributed Energy Resources Customer Adoption Model Technology Data." http://der.lbl.gov/tech_data.html.

Goldstein, L., B. Hedman, D. Knowles, S.I. Freedman, R. Woods, T. Schweizer. 2003. "Gas-Fired Distributed Energy Resource Technology Characterizations" Golden, CO: National Renewable Energy Laboratory report NREL/TP-620-34783.

Hui, S.C.M.. "DOE-2.1E Basics Manual.” August 2001. http:/gundog.lbl.gov/ referenced 13 May 2004 from the Building Simulation Group web page at Berkeley Lab.

NBVC Public Works. “Top Utility Consumers for FY 03.” Received December 2003.

NBVC Public Works. “Interim Installation Assessment Report.” Received December 2003.

PM Meter Readings FY-03. Provided by Deborah Stewart, Public Utilities Specialist, NBVC. December 2003.

Southern California Edison. SCE TOU-8 and SCE TOU-8 Direct Access tariffs and Departing Load reference document provided by Nathan Smith at SCE.

Nathan.Smith@sce.com.

Southern California Gas Company. August 2001. "Naval Base Ventura County Standby Generator Optimization Review." 



\section{Appendix A. Model Structure}

\section{A.1.1 Three Day Type Model}

The DER-CAM program uses three types of days to model energy use: weekday, peak day, and weekend. Week and weekend days are obtained by averaging all the days of that type, for each hour, into a representative day with an hourly profile. Hence, the week and weekend days are average days. Peak days represent the three highest load days of each month. The peak day for each month was observed in the DOE-2 output and replicated as the peak day.

The representative load profile for each day type was multiplied by the corresponding number of days per month in 2004 to obtain the total energy load use for of the five end uses. The three peak days were obtained by subtracting two days from the week days and one day from the weekend totals. Exceptions were February, August, and October, where the two peak days were taken from the weekend days and one from the weekdays, because these months had weekend peaking loads in DOE-2 for each of the three buildings simulated. The number of each day type multiplied by its total load each month determines the total load for that month. These values were then summed and compared to the average meter read data obtained from Public Works. The DOE-2 model estimates for load data were slightly higher than the meter data average. Electric-only and cooling loads were multiplied by 0.96 and space- and water-heating, and natural-gas-only loads were multiplied by 0.85 to correspond with average electric and natural gas meter data.

\section{A.1.2 Interest Rate}

The interest rate for calculating the annual cost of capital equipment is $5 \%$ real compounded annually.

\section{A.1.3 Parameter Inputs to DOE-2}

DOE-2 needs a set of parameter inputs. The DOE-2 weather file TMY2for Santa Maria, CA was chosen because it most closely describes conditions at the bases. Floor space of each component building was also input. Building 1512 floor space was assumed divided among the NEX, Commissary, and food court according to Table A- 1 .

Table A- 1: Area of each Section of Building 1512

\begin{tabular}{|l|r|}
\hline Building & Size $\mathbf{~ m}^{\mathbf{2}}\left(\mathbf{f t}^{\mathbf{2}}\right)$ \\
\hline NEX & $7,600(82,000)$ \\
\hline Commissary & $4,500(49,000)$ \\
\hline Food Court & $500 \quad(5,400)$ \\
\hline
\end{tabular}





\section{Appendix B. $\quad$ Assumptions in Modeling Process}

\section{B.1.1 Assumptions Made for Modeling Building 1512 at NBVC}

Modeling Building 1512 required the following parameter input assumptions:

- The load, tariff, technology and other input parameter characterizations are correct and unchanging over the analysis period.

- The financial analysis is performed over a period of one year, with the DER equipment capital cost amortized over the 10 to 30 year equipment lifetime.

- The DOE-2 output is correct and linearly scalable. In other words, when energy use estimates disagree with actual data, the load profiles can be scaled to meet actual data and remain valid.

- All decisions are made within the same year: all technology, load, and tariff information is concurrent.

- All technology cost and performance data is accurate and known by all the decision makers involved in the process. Furthermore, a DER system's cost does not change during a project's installation period or after it is operating.

- All technologies in the model fall into one of three types depending upon their output capability: DG (distributed generation, electricity only); DG with CHP (heat recovery) capability; or DG, CHP, and absorption cooling capability.

- The DER CHP and absorption chilling systems are considered retrofits to the existing heating and cooling systems in each building. The DER system serving the Commissary and NEX would be connected both with the existing natural-gas-fired boiler or furnace to meet residual heating loads and with the compressor-driven air conditioning system currently used to meet cooling loads. This equipment operates at average efficiency.

- Absorption cooling is used to displace compressor cooling. However, in order to avoid altering the cooling load input data, the absorption cooling is also assigned a certain "phantom" electrical output at zero cost. This should result in accurately representing the capital and operating costs, as well as the performance characteristics of absorption cooling equipment while simultaneously substituting for electricity powered cooling equipment without affecting the electrical load data. After electrical load data are input in the model, mixed integer programming optimization will not modify it.

- Since the performance of the DER systems is typically given only at maximum capacity in the specification sheets, each DER unit operates at constant efficiency and COP (coefficient of performance) over the range of output. That is, the amount of heating or cooling a unit produces is proportionally related to the percent of electrical capacity the unit is producing. The ratio of heating or cooling output per unit of electric output is also fixed. In other words, 
the efficiency of fuel input and energy output per unit of electricity production capacity is fixed throughout the technology's operation.

- In the process of defining the heating and cooling loads for each particular site, only those that could be met by CHP systems are selected. Others are included as natural-gas-only loads. These heating and cooling loads are accurate models of those in the buildings. In other words, the DOE-2 model accurately estimates the heating and cooling loads and selectes only the specific portions that can be met with CHP.

- The manufacturer performance specifications are correct and the price estimates representative for the area and time period studied. Capital costs in $\$ / \mathrm{kW}$ are turnkey costs with system design, and purchase and installation costs all included.

- The DER equipment maintains a load-following capability. That is, electric loads are met with DER output while heating and cooling needs are met with a combination of CHP output (also based on electricity production) and assistance from the supplementary heating and cooling systems.

- Ancillary loads of absorption chillers are ignored. This is reasonable since a standard absorption cooling system has only two water pumps. Pumping a liquid uses substantially less energy than a compressor cooling system.

- Since there is no thermal heat, production has to meet heating and cooling for each hour of the day. In other words, the building does not have thermal mass and cannot "inventory" heat from one hour to the next. However, heating and cooling loads can be reduced during off peak hours to reflect the reduced demand for energy at those times.

Heat flow uses $\mathrm{kW}$ (power) on an hourly basis. Heat is all the same quality, it flows where it is directed and delivered with efficiency of parameter $\gamma$ to loads, where $\gamma$ is equal to 0.8 for CHP served heating loads and 0.13 for absorption chiller served cooling loads. To model each individual thermal load application accurately, the end use type and its heat flow capacity need to be specified in DER-CAM along with the hourly heat flow rates, the distances from heat source to heat sink, the pressure of the heat transfer medium, and the efficiency curves of generators and heat exchangers.

\section{B.1.2 Efficiency Calculations}

The efficiency values cited are whole system efficiencies that include loads served and fuel required by the macrogrid, natural gas delivery network, and the on-site DER system.

Efficiency is the sum of all the end-use load requirements in $\mathrm{kWh}$ for both electric and gas, divided by the fuel requirement for each load. The efficiency of the macrogrid is assumed to be 0.33 . The fuel requirement is derived by dividing the load by the efficiency, thereby calculating the primary fuel input as a function of efficiency. The electricity produced from the DER system and the fuel consumed are provided as DER-CAM output. DER-CAM output includes loads met by purchased natural gas delivered on site with an efficiency of 1 (natural gas to natural gas 
load). The delivery efficiency of the natural gas transportation network is assumed to be 0.8 . Hence, the primary fuel requirements necessary to serve the natural gas loads are found by dividing the load by 0.8 .

Thermal loads met by CHP are also provided as an output from DER-CAM and are assumed to require no additional fuel input since it has already been included for the system.

DER system efficiency, if cited, is calculated by adding the electricity output of the equipment to the thermal loads served by CHP (in kWh), and dividing by the fuel consumed to run the equipment. This is a narrower view of the DER system efficiency and does not include the efficiency of the natural gas delivery infrastructure.

Carbon emissions are calculated from the fuel input requirements. Electric energy is assumed to produce $0.165 \mathrm{~kg} / \mathrm{kWh}$ and natural gas $0.048 \mathrm{~kg} / \mathrm{kWh}$. 



\section{Appendix C. Limitations of Analysis}

Actual data for the different end-use loads were not available, especially on the hourly basis DER-CAM requires as input so DOE-2 building simulation was used to generate them. The loads were then scaled to reflect the magnitude of the data read from the electric and gas meters each month at Building 1512. This process develops rough load curves, but may miss some of the important characteristics suitable for integration with a DER system. Refrigerator, freezer, and chilled display case loads in the Commissary and NEX, for example, would make substantial loads for a residual heat driven absorption chiller. The DOE-2 modeling method used to generate building loads for DER-CAM, however, considers the electricity used here to be electric-only loads which cannot be met by absorption chillers.

Insolation values for Southern California (San Diego) were used but more accurate data for Port Hueneme could be obtained if further analysis with PV is completed.

The analysis uses historic estimated loads and assumes the electricity and gas tariffs are constant throughout the year. Historical electricity and gas bills reveal that commodity prices for both electricity and natural gas fluctuated greatly over the last 12 months.

Capital costs for installing the technology are general and may not reflect site-specific conditions influencing the technology configuration and design and installation costs. 



\section{Appendix D. Technology Performance and Price Information ${ }^{7}$}

\section{D.1 Technology Performance and Price Parameters}

To be consistent, DER technology capital costs and performance specifications are primarily taken from the TeChars report (Goldstein et al., 2003). Table A- 2 describes the technology cost and performance information used in DER-CAM. The CPUC SelfGen grants were then included, reducing the capital cost of applicable technologies.

Table A- 2: DER-CAM Technology Cost and Performance Information

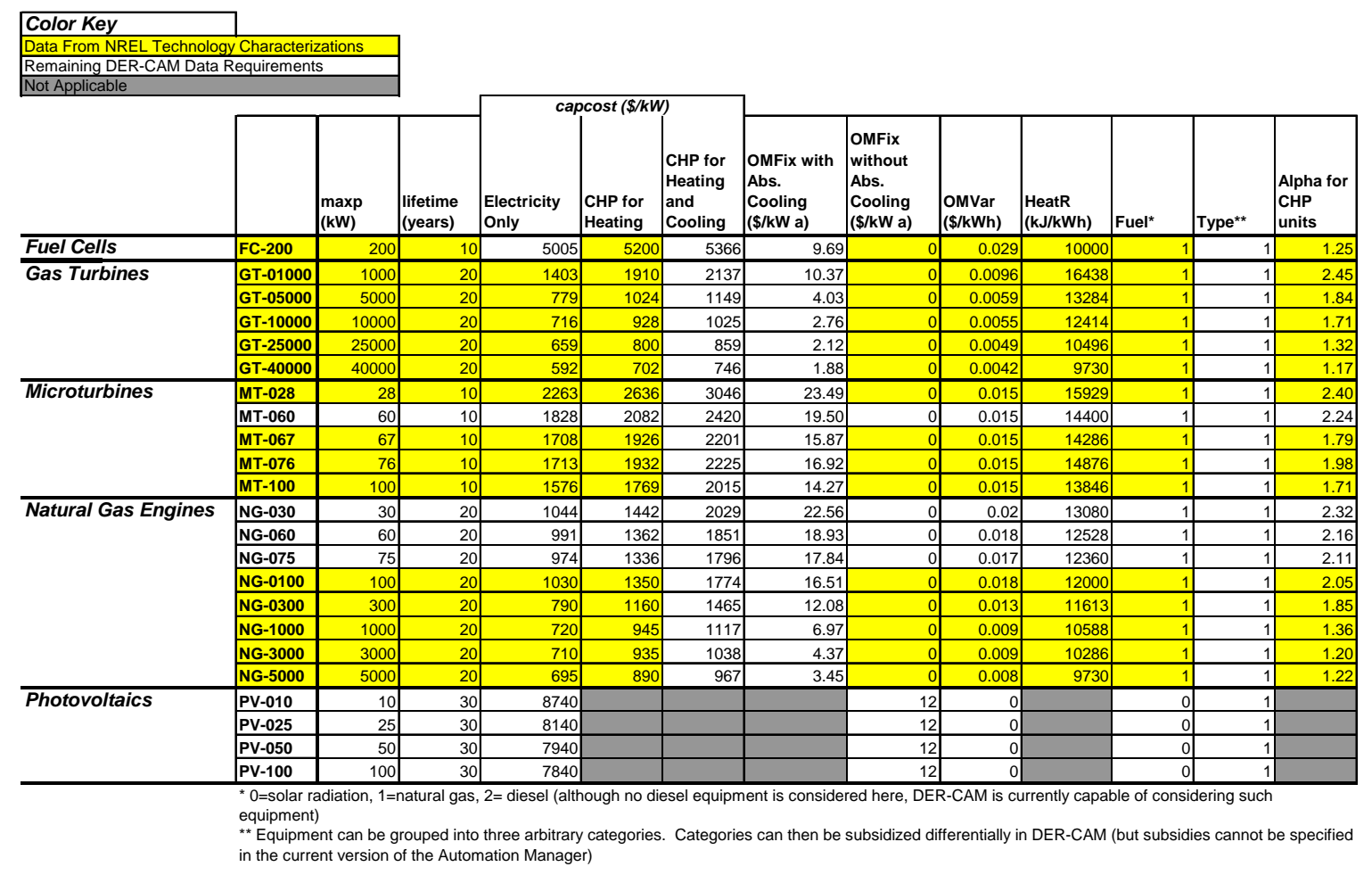

source: Firestone, January 2004.

The following is a description of the parameters characterizing each technology in DERCAM.

\section{D.1.1 Rated Capacity (maxp)}

Maxp is the rated maximum electrical output $(\mathrm{kW})$ of the equipment.

\footnotetext{
${ }^{7}$ See Firestone, Ryan, DER-CAM Technology Data, January 2004 for complete description of technology parameters.
} 


\section{D.1.2 Lifetime}

Lifetime is the expected life of the equipment in years. No distinction is made between equipment life and financial life. The capital cost of the technology is converted to an annual annuity dispersed over the lifetime of the equipment. All other cost and performance characteristics are assumed constant over this period.

\section{D.1.3 Capital Costs (Capcost)}

Capcost is the turnkey cost representation including equipment, system design, delivery, and installation. When appropriate, generation equipment can be purchased

- without heat recovery capabilities,

- with heat recovery for heating only, or

- with heat recovery for both heating and absorption cooling ${ }^{8}$

Capcost is expressed as the cost per $\mathrm{kW}$ of rated electrical capacity $(\$ / \mathrm{kW})$.

\section{D.1.4 Operation and Maintenance Fixed Costs (OMFix)}

OMFix includes all fixed annual operation and maintenance costs $(\$ / \mathrm{kW} \cdot \mathrm{a})$ of the equipment, excluding fuel costs.

\section{D.1.5 Operation and Maintenance Variable Costs (OMVar)}

OMVar includes all variable operation and maintenance costs $(\$ / \mathrm{kWh})$ of the equipment, excluding fuel costs, of the equipment

\section{D.1.6 Heat Rate (HeatR)}

Heat $\boldsymbol{R}$ is the heat rate $(\mathrm{kJ}$ fuel $/ \mathrm{kWh})$, which is related to electrical efficiency, $\mu_{\mathrm{e}}$, by (Equation 1).

$$
\text { HeatR }=\frac{3600 \mathrm{~kJ} / \mathrm{kWh}}{\mu_{e}}
$$

Equation 1

HeatR is specified in DER-CAM using the higher heating value (HHV) of natural gas, which is consistent with the purchase price of natural gas. Manufacturers often use the lower heating value (LHV) of natural gas when calculating the heat rate and efficiency for technology specifications. ${ }^{9}$

\footnotetext{
${ }^{8}$ Absorption cooling and heat recovery for heating both require the same heat exchanger for producing hot water. Therefore, a system capable of utilizing recovered heat for absorption cooling can also use recovered heat for heating.

${ }^{9}$ An average value for the HHV of natural gas is $38.3 \mathrm{MJ} / \mathrm{m}^{3}$ while for the LHV it is $34.6 \mathrm{MJ} / \mathrm{m}^{3}$ (ORNL, (1)). Thus, the ratio of LHV to HHV is 0.903 . An electrical efficiency stated with respect to the LHV of natural gas can be multiplied by this ratio to determine the efficiency with respect to the HHV of natural gas.
} 


\section{D.1.7 Heat to Power Ratio $(\alpha)$}

$\boldsymbol{\alpha}$ is the flow of recoverable heat $(\mathrm{kW})$ per unit $(\mathrm{kW})$ of electricity generated.

In DER-CAM, $\alpha$ is based on the waste heat energy content prior to conversion via a heat exchanger, referred to here as recoverable heat. TeChars specifies an electrical power-toheat ratio based on the waste heat energy content after conversion via a heat exchanger, referred to here as useful heat. To account for this difference, the Berkeley Lab assumes heat exchangers of $80 \%$ effectiveness. Thus, power-to-heat ratios from TeChars are multiplied by 0.8 to correspond with the definition of $\alpha$ used in DER-CAM. The inverse of this modified power-to-heat ratio is the alpha used by DER-CAM (Equation 2).

$$
\alpha=\left(\left(\frac{\text { Power }}{\text { Heat }}\right)_{\text {NREL }} \times \text { HeatExchangerEffectiveness }\right)^{-1} \quad \text { Equation } 2
$$

\section{D.2 Other Input Parameters}

\section{D.2.1 DER-CAM Parameters}

The following sections describe some of the parameters used in DER-CAM to characterize the heat flow between DER technologies and the end-use loads.

\section{D.2.2 Conversion Efficiency for Recoverable Heat to Load Displacement $(\gamma)$}

$\gamma$ is an estimate of the portion of recoverable heat that can be used for displacing heating loads through heat exchangers or cooling loads via absorption chillers. $\gamma$ for hot water and space heating loads is the heat exchanger effectiveness. DER-CAM currently assumes a value of 0.8 for $\gamma$ for heat loads.

Cooling loads in DER-CAM are defined as the amount of electricity required to provide the desired level of cooling, assuming a specified value for electric chiller efficiency. $\gamma$ for absorption cooling is, therefore, the ratio of electrical cooling load displacement to recoverable heat. This value must incorporate heat exchanger effectiveness as well as the relative performance of electric and absorption chillers as described in Equation 4, where $\mathrm{COP}_{\text {abs }}$ is the coefficient of performance of an absorption chiller ${ }^{10}$ and $\mathrm{COP}_{\text {electric }}$ is the coefficient of performance of an electric chiller. COP is defined below.

$$
\begin{array}{ll}
C O P=k W \text { cooling out } / k W \text { electricity in } & \text { Equation } 3 \\
\gamma_{\text {abs }}=\text { Effectiveness }_{\text {HeatEx }} * \frac{C O P_{\text {abs }}}{C O P_{\text {electric }}} & \text { Equation } 4
\end{array}
$$

\footnotetext{
${ }^{10}$ The coefficient of performance (COP) of a chiller is the ratio of heat removed by the chiller to energy (electricity or heat) provided to the chiller.
} 
$\mathrm{COP}_{\mathrm{abs}}$ has an assumed value of 0.65 for single-stage hot-water fired absorption chillers and $\mathrm{COP}_{\text {electric }}$ has an assumed value of 4 for electric compression driven chillers ${ }^{11}$. Thus, $\gamma_{\mathrm{abs}}$ has a value of 0.13 for CHP absorption chillers.

\section{D.2.3 Conversion Efficiency for Fuel to Load Displacement $(\beta)$}

$\beta$ is an estimate of available heat output $(\mathrm{kW})$ per unit $(\mathrm{kW})$ of purchased fuel (e.g., natural gas) input that can be used for displacing heat loads through heat exchangers or cooling loads in absorption chillers. For heat loads, this is the boiler efficiency. DERCAM currently assumes a value of 0.8 for $\beta$ for heat loads and 0 or 0.13 for cooling loads. The different cooling load values depend on whether natural gas can be burned for booster heat to the hot water supply of an indirect fired absorption chiller.

The $\beta$ value for cooling loads is lower than that for heating loads because DER-CAM expresses cooling loads as the amount of electricity requested to provide the desired amount of cooling, and cooling load is invariably expressed as electricity used by an air conditioning system. Thus, $\beta$ for absorption chillers must incorporate the ratio of useful heat output to fuel energy input as well as the relative performance of electric and absorption chillers, as discussed in Section D.2.2 above. It is assumed that direct natural gas combustion can be used to supplement recovered heat in supplying the heat load to the absorption chiller. Because heat exchanger effectiveness and boiler efficiency both have an assumed value of $0.8, \beta$ and $\gamma$ have the same values.

\section{D.2.4 $\beta$ and $\gamma$ Values}

Table A- 3 presents the underlying assumptions used to generate $\beta$ and $\gamma$ values for DERCAM. Table A- 4 presents the $\beta$ and $\gamma$ values used.

\section{Table A- 3: Underlying Assumptions Used For $\beta$ and $\gamma$ Values}

Underlying Assumptions
\begin{tabular}{|l|r|}
\hline Heat Exchanger Effectiveness & 0.8 \\
\hline Boiler Efficiency & 0.8 \\
\hline COP, absorption chiller & 0.65 \\
\hline COP, electric chiller & 4 \\
\hline
\end{tabular}

\footnotetext{
${ }^{11}$ DER-CAM assumes that sites have electric chillers installed prior to DER considerations. A COP of 4 is an approximation of chiller performance for units currently installed in the United States. Actual COPs of electric chillers can vary widely by product and conditions of use, such as temperature differential between hot inlet and cold outlet.
} 
Distributed Energy Resources at Naval Base Ventura Country Building 1512

Table A- 4: $\beta$ and $\gamma$ Definitions

\begin{tabular}{|c|c|c|c|c|}
\hline & beta & & gamma & \\
\hline end-use & formula & value & formula & value \\
\hline electricity-only & $\beta_{\text {electric }}=0$ & 0 & $\gamma_{\text {electric }}=0$ & 0 \\
\hline cooling & $\beta_{a b s}=$ Efficiency $_{\text {boiler }} * \frac{C O P_{a b s}}{C O P_{\text {electric }}}$ & 0.13 & $\gamma_{a b s}=$ Effectiven ess ${ }_{\text {HeatEx }} * \frac{C O P_{a b s}}{C O P_{\text {electric }}}$ & 0.13 \\
\hline space-heating & $\beta_{\text {heating }}=$ Efficiency $_{\text {boiler }}$ & 0.8 & $\gamma_{\text {heating }}=$ Effectiven ess ${ }_{\text {HeatEx }}$ & 0.8 \\
\hline water-heating & $\beta_{\text {heating }}=$ Efficiency $_{\text {boiler }}$ & 0.8 & $\gamma_{\text {heating }}=$ Effectiven ess ${ }_{\text {HeatEx }}$ & 0.8 \\
\hline naturalgas-only & $\beta_{\text {naturalGas }}=1$ & 1 & $\gamma_{\text {naturalGas }}=0$ & 0 \\
\hline
\end{tabular}





\section{Appendix E. CPUC Self-generation Incentive Program ${ }^{12,13}$ :}

After passage of California Assembly Bill 970 in September 2000, the CPUC approved SelfGen, a statewide self-generation incentive program providing rebates to customers who install new qualifying self-generation equipment to meet all or a portion of their electrical needs. The program provides $\$ 125$ million annually statewide and is administered by Pacific Gas and Electric (PG\&E), Southern California Edison (SCE), Southern California Gas Company (SoCalGas), and the San Diego Regional Energy Office (SDREO).

Table A- 5: Technologies Eligible for CPUC Self-Generation Rebates ${ }^{14}$

\begin{tabular}{|c|c|c|c|c|c|}
\hline $\begin{array}{c}\text { Incentive } \\
\text { Category }\end{array}$ & $\begin{array}{c}\text { Incentive } \\
\text { Offered }\end{array}$ & $\begin{array}{c}\text { Maximum } \\
\text { \% of } \\
\text { Project } \\
\text { Cost }\end{array}$ & $\begin{array}{c}\text { Minimum } \\
\text { System Size }\end{array}$ & $\begin{array}{c}\text { Maximum } \\
\text { System } \\
\text { Size* }\end{array}$ & $\begin{array}{c}\text { Eligible } \\
\text { Technologies }\end{array}$ \\
\hline $\begin{array}{c}\text { Level 1 } \\
\text { Level 2 }\end{array}$ & $\$ 4500 / \mathrm{kW}$ & $50 \%$ & $30 \mathrm{~kW}$ & $1.5 \mathrm{MW}$ & $\begin{array}{l}\text { photovoltaics, fuel cells } \\
\text { operating on renewable } \\
\text { fuel, and wind turbines }\end{array}$ \\
\hline $\begin{array}{c}\text { Level 3-R } \\
\text { Renew- } \\
\text { able }\end{array}$ & $\$ 1500 / \mathrm{kW}$ & $40 \%$ & None & $1.5 \mathrm{MW}$ & $\begin{array}{l}\text { fuel cells operating on } \\
\text { non-renewable fuel and } \\
\text { utilizing sufficient } \\
\text { waste heat recovery }\end{array}$ \\
\hline $\begin{array}{c}\text { Level 3-N } \\
\text { Non- } \\
\text { renew- } \\
\text { able }\end{array}$ & $\$ 1000 / \mathrm{kW}$ & $30 \%$ & None & $\begin{array}{l}\text { microturbines, small } \\
\text { gas turbines, internal } \\
\text { combustion engines, } \\
\text { operating on renewable } \\
\text { fuel }\end{array}$ \\
$\begin{array}{c}\text { * Maximum system size 1.5 MW, but rebate funding only available up to a 1 MW cap } \\
\text { * }\end{array}$ & $\begin{array}{l}\text { microturbines, small } \\
\text { gas turbines, internal } \\
\text { combustion engines, } \\
\text { using sufficient waste } \\
\text { heat recovery and } \\
\text { meeting reliability } \\
\text { criteria }\end{array}$ \\
\hline
\end{tabular}

For program purposes, self-generation refers to clean distributed generation technologies, such as microturbines, fuel cells, photovoltaic, small gas turbines, wind turbines, and internal combustion engines, which meet the following criteria:

- At least $5 \%$ of the power system's total energy output is in the form of useful thermal energy.

\footnotetext{
${ }^{12}$ CPUC Self-Generation Incentive Program July-December 2001 Status Report, referenced May 2004, http://www.cpuc.ca.gov/published/report/13690.htm

${ }^{13}$ San Diego Regional Energy Office, San Diego SelfGen, May 2004, http://www.sdge.com/business/self_generation.shtml

${ }^{14}$ San Diego Regional Energy Office, San Diego SelfGen Program, May 2004, http://www.sdge.com/business/incentive_programs.shtml\#self
} 
- Where useful thermal energy results from power production, the useful annual electrical output plus one-half the annual useful thermal energy output equals not less than $42.5 \%$ of any natural gas and oil energy input.

- Microturbines, small gas turbines, and internal combustion engines must meet the following power quality and reliability requirements:

- The self-generating facility must be designed to operate in power factor mode such that the generator operates between 0.95 power factor loading and 0.90 power factor leading. - Sites with greater than $200 \mathrm{~kW}$ generating capability must coordinate maintenance schedules with the local utility, and in general can only schedule maintenance from October to March, and if necessary only during off peak or weekend hours between April and September.

The CPUC funding limits are a secondary source and are decreased by the amount of alternate funding. In other words, the CPUC represent a cap on funding available. It is assumed, therefore, that the qualifying California test sites will receive funding up to the limits set by this program. 


\section{Appendix F. $\quad$ Appendix Load Profiles}

\section{F.1 Load Profiles}

Ideally, complete electric and thermal load profiles from hourly readings for a full year (historical, or even better, forecast) would be available as inputs to DER-CAM. At NBVC, however, the load data consisted of four years of monthly electric and gas meter readings (November 1998 to January 2004) for both the Commissary and NEX. Data from the period between September 2001 and July 2002 had to be discarded because it was incomplete (the missing data was obtained for the Commissary but not for the NEX). The remaining monthly electric and natural gas data were averaged to obtain baseline monthly electric and natural gas consumption.

The DOE-2 building energy simulator was used to develop hourly electricity, heating, and cooling loads, which were otherwise unavailable. A simplified user interface was developed for DER-CAM modeling, from which hourly load information was generated based on building type, location, interior area, and known information about the building's energy consumption. Output data were generated as hourly reports containing selected DOE-2 output specifications.

The DOE-2 model was used to develop load profiles for the following building types: retail store (NEX), supermarket (Commissary), and fast food restaurant (the food court). The outputs were added to total the loads for Building 1512's major components and then scaled to match the data.

The DER-CAM load input is a matrix containing average hourly load data by weekday and weekend for the twelve months of the year. Thus, there are 24 rows of data per load type. There are five end-use load types, giving a total of 120 rows of load data, with 24 columns. The five DER-CAM load types used in this study are:

- electric-only: loads met only by electricity which cannot be met by natural gas or CHP heat (lighting, computing, etc.).

- space cooling: loads met by electricity or heat recovery through absorption chillers.

- space heating: loads met either directly by natural gas or with residual heat from CHP.

- water heating: loads met either directly by natural gas or with residual heat from CHP.

- natural-gas-only: loads met only by natural gas and not CHP opportunities (primarily cooking loads).

DOE-2 output was converted to appropriate SI units (Système International d'unités), and then each load profile was added to one of the five end-use load types. This involved estimation of the type of energy system DOE-2 modeled during the load profile generation.

A Visual Basic for Applications macro built into Microsoft Excel converts DOE-2 output to the format DER-CAM needs. An hour-by-hour load profile for each month was averaged from hourly load profiles for each day of the year ( 8760 hours total), end use, and day type. This macro also recorded the peak hourly load for each month and each day type, and then used that information to develop a "peak day" load shape for each month and load type. 
These load profiles were displayed in a spreadsheet and calibrated to match information provided by Public Works regarding the energy use in Building 1512. Electric-only and cooling loads from DOE-2 were multiplied by a factor of 0.96 to correspond to the average annual loads provided by historic meter readings. The space heating, water heating, and natural-gas-only loads from DOE- 2 were multiplied by 0.85 to correspond to the average annual loads provided by meter readings from November 1998 to January 2004.
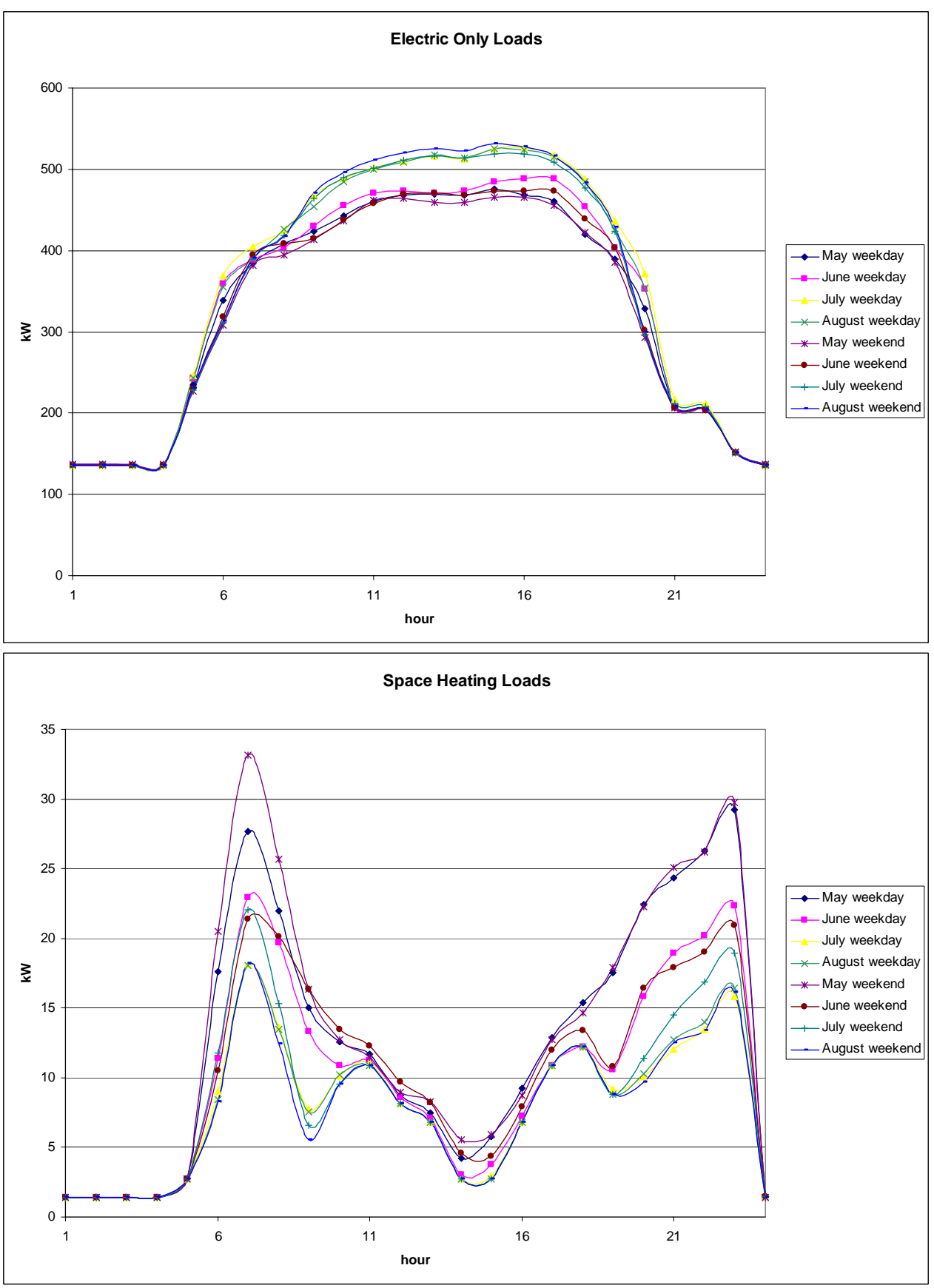
Distributed Energy Resources at Naval Base Ventura Country Building 1512

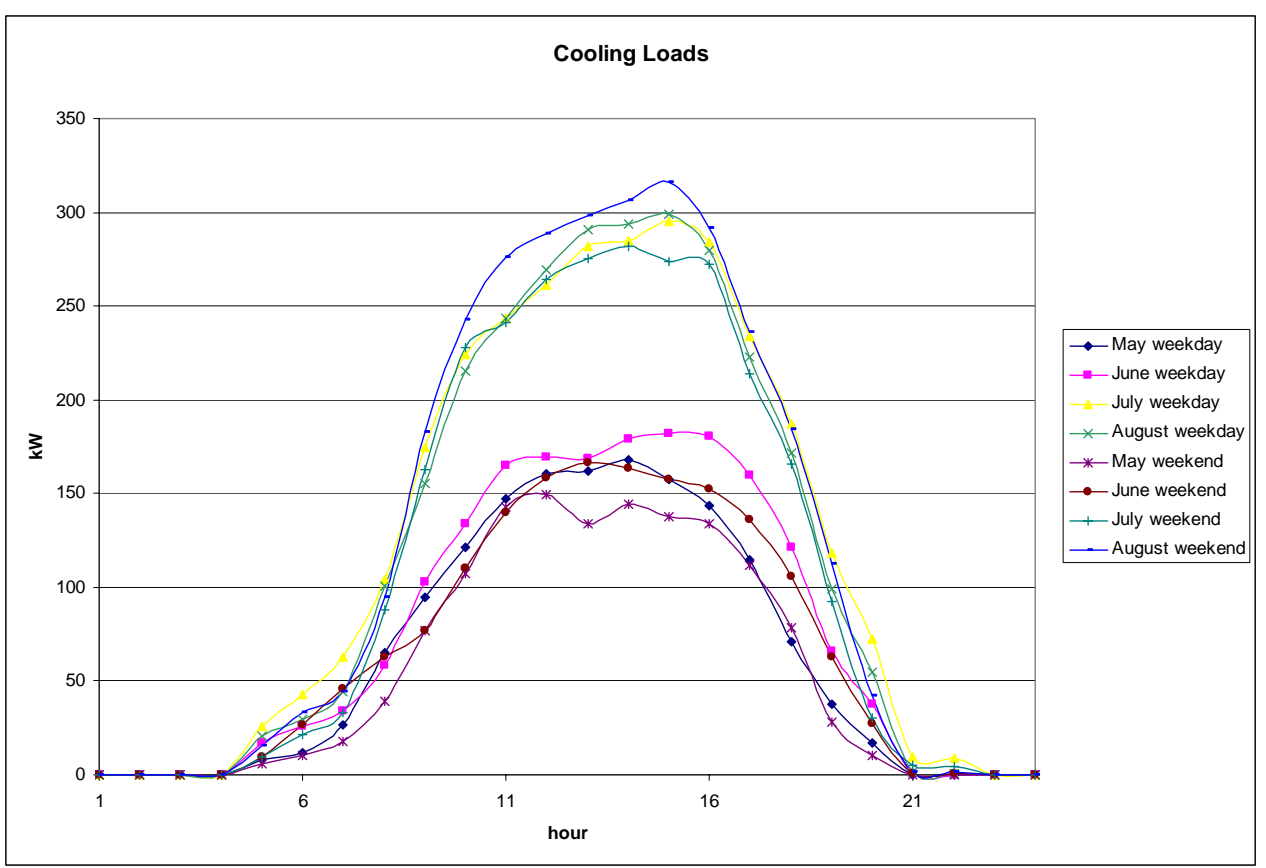

Figure A- 1: Load Profiles for Building 1512 



\section{Appendix G. Tariff Information}

\section{G.1 Summary of NBVC Tariff}

\section{G.1.1 Direct access}

NBVC has a direct access contract with an energy service provider, Strategic Energy, and electricity delivery services through SCE under tariff TOU-8 direct access. The Strategic Energy contract is effective through March 2005 and renewable indefinitely. ${ }^{15}$ Natural gas is purchased from a direct supplier and SoCalGas is paid for its delivery. The net tariff estimated by combining the Strategic Energy charge and the SCE TOU-8 direct access charge is here called the direct access tariff.

In summary, NBVC tariffs currently have the following components:

- Strategic Energy: direct access supplier and

- SCE consisting of the following components:

- $\quad$ Schedule TOU-8

- Schedule DA-CRS: Direct Access Cost Responsibility Surcharge

- Schedule DL-NBC: Departing Load Nonbypassable Charges

- Schedule S Standby.

Table A- 6 shows the actual tariffs NBVC is charged by adding Strategic Energy's rates for electricity generation and SCE's delivery service rates under the direct access tariff. These prices are calculated using June 2004 bills and assume the direct access prices will remain constant. Figure A- 2 below shows the commodity prices for electricity charged by Strategic Energy. The direct access cost responsibility surcharge (DA-CRS) consists of $\$ 0.00493 / \mathrm{kWh}$ for the DWR Bond Charge and $\$ 0.01 / \mathrm{kWh}$ for the historic procurement charge (HPC) to recover direct access customers' share of SCE's Procurement Related Obligations Account. The residual $\$ 0.01207 / \mathrm{kWh}$ is applied to the DWR 2004 Power Charge. ${ }^{16}$

\footnotetext{
${ }^{15}$ Veronica Jarvis, Strategic Energy, personal communication, March 2004.

${ }^{16}$ SCE's Schedule DA-CRS, Filed Jan 22, 2004, effective Feb 1, 2004.
} 
Table A- 6: Direct Access Tariff Components at NBVC

\begin{tabular}{|l|l|l|l|l|l|}
\hline & $\begin{array}{l}\text { Strategic } \\
\text { energy } \\
\mathbf{( \$ / k W h )}\end{array}$ & $\begin{array}{l}\text { SCE TOU-8 } \\
\text { Direct Access } \\
\text { Delivery } \\
\text { Service } \\
\mathbf{( \$ / k W h )}\end{array}$ & $\begin{array}{l}\text { SCE TOU-8 } \\
\text { HPC, DWR } \\
\text { Power and } \\
\text { Bond } \\
\text { charges }\end{array}$ & $\begin{array}{l}\text { Total Tariff } \\
\text { TOU rate } \\
\mathbf{( \$ / k W h )}\end{array}$ & $\begin{array}{l}\text { Total } \\
\text { Demand } \\
\text { Charges } \\
\mathbf{\$} / \mathbf{k W}\end{array}$ \\
\hline $\begin{array}{l}\text { On Peak } \\
\text { Summer }\end{array}$ & 0.0643 & 0.00686 & 0.027 & 0.09816 & 6.91 \\
\hline $\begin{array}{l}\text { Mid Peak } \\
\text { Summer }\end{array}$ & 0.0643 & 0.00686 & 0.027 & 0.09816 & 0.46 \\
\hline $\begin{array}{l}\text { Off Peak } \\
\text { Summer }\end{array}$ & 0.0643 & 0.00686 & 0.027 & 0.09816 & 0 \\
\hline $\begin{array}{l}\text { On Peak } \\
\text { Winter }\end{array}$ & 0.0643 & 0.00686 & 0.027 & 0.09816 & 1.61 \\
\hline $\begin{array}{l}\text { Mid Peak } \\
\text { Winter }\end{array}$ & 0.0643 & 0.00686 & 0.027 & 0.09816 & 0 \\
\hline $\begin{array}{l}\text { Off Peak } \\
\text { Winter }\end{array}$ & 0.0643 & 0.00686 & 0.027 & 0.09816 & 0 \\
\hline
\end{tabular}

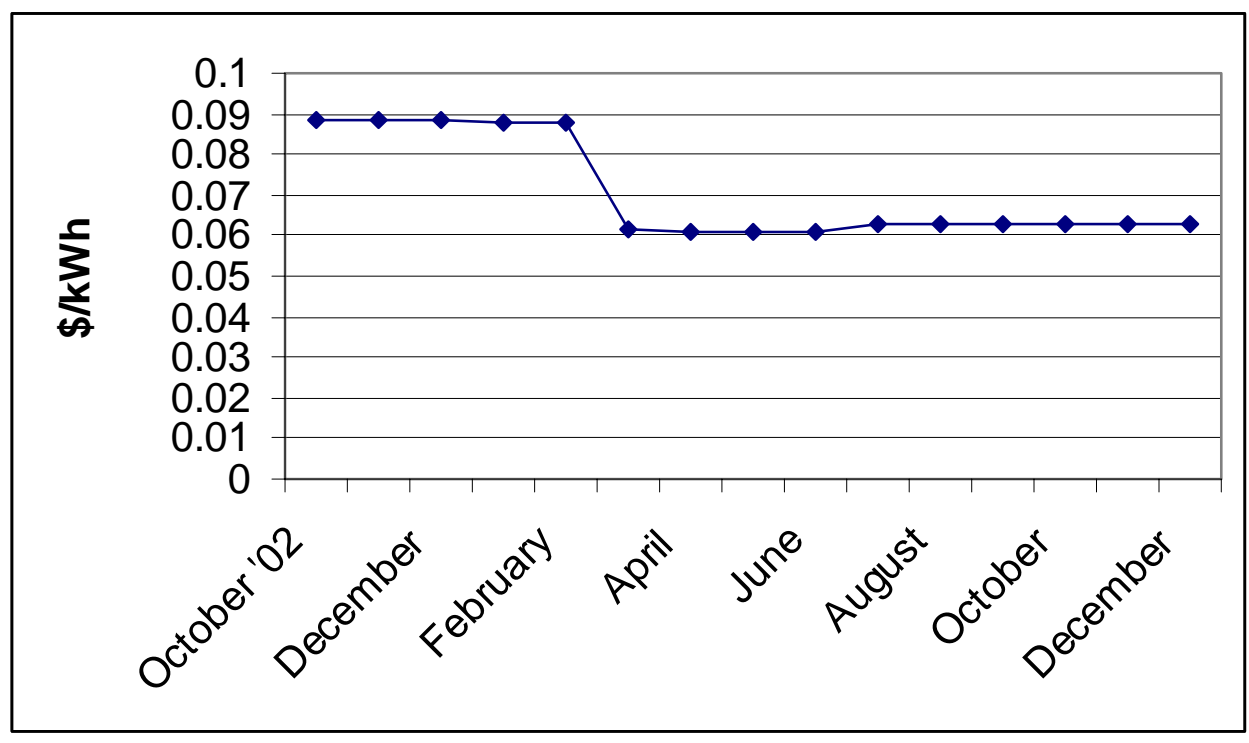

Figure A- 2: Direct Access Energy Supply Prices by Strategic Energy 
Other direct access tariff characteristics

Customer charge (\$/meter/month):

224.22

Facility charges

Facility charge ( $\$ \mathrm{~kW} /$ month):

Power Factor Adjustment (\$/KVA/month):

0.1028

Assume reactive power near zero so it is $\$ / \mathrm{kW} /$ month)

Total Facility charge $(\$ / \mathrm{kW} /$ month):

Time dependent demand charges ( $\$ / \mathrm{kW} /$ month)

On-peak summer:

Mid-peak summer

0.46

Else:

0

Standby charge ( $\$ / \mathrm{kW} / \mathrm{meter} /$ month)

With direct access $(\$ / \mathrm{kV} /$ meter/month) $\quad 0.44$

Departing load $(\$ / \mathrm{kWh}$ from DER $/$ month $) \quad 0.00191+0.00191=0.00382$

Add this to O\&M variable cost of each DG unit

Schedule SSGDR Simplified Self Generation Deferral Rate: not applicable ${ }^{17}$

\footnotetext{
${ }^{17}$ Nathan Smith, SCE, personal communication, July 2004.
} 


\section{G.1.2 SCE TOU-8}

The SCE tariff that would be effective if the base had not entered into the direct access agreement before September 20, 2001 is called the SCE TOU-8 tariff after the SCE tariff rate for large customers obtaining electric service over $50 \mathrm{kV}$. Direct access is not available for contracts entered into after September 20, 2001. ${ }^{18} \mathrm{NBVC}$ is receiving power at 66 to $115 \mathrm{kV}$. ${ }^{19}$ This is the applicable tariff rate NBVC would receive if they do not to renew the direct access contract before March 2005, future tariff changes notwithstanding. Table A- 7 describes the energy and demand components of SCE TOU-8.

Table A- 7: SCE TOU-8 Tariff

\begin{tabular}{|l|l|l|l|l|}
\hline & $\begin{array}{l}\text { SCE TOU-8 } \\
\text { Delivery Service } \\
\mathbf{( \$ / k W h )}\end{array}$ & $\begin{array}{l}\text { SCE TOU-8 } \\
\text { Generation } \\
\text { Service } \mathbf{( \$ / k W h ) ~}\end{array}$ & $\begin{array}{l}\text { SCE TOU-8 } \\
\text { Total } \mathbf{( \$ / k W h )}\end{array}$ & $\begin{array}{l}\text { Total Demand } \\
\text { Charges \$/kW }\end{array}$ \\
\hline On Peak Summer & 0.01179 & 0.107443 & 0.11869 & 15.01 \\
\hline $\begin{array}{l}\text { Mid Peak } \\
\text { Summer }\end{array}$ & 0.01179 & 0.055479 & 0.06826 & 2.03 \\
\hline $\begin{array}{l}\text { Off Peak } \\
\text { Summer }\end{array}$ & 0.01179 & 0.04739 & 0.06041 & 0 \\
\hline $\begin{array}{l}\text { On Peak Winter } \\
\text { On }\end{array}$ & 0.01179 & 0.061964 & 0.07456 & 1.61 \\
\hline Mid Peak Winter & 0.01179 & 0.061964 & 0.07456 & 0 \\
\hline Off Peak Winter & 0.01179 & 0.048107 & 0.06111 & 0 \\
\hline
\end{tabular}

Other SCE TOU-8 tariff characteristics

Customer charge (\$/meter/month):

349.45

Facility Charges

Facility charge ( $\$ / \mathrm{kW} /$ month):

Power Factor Adjustment (\$0.18/KVA/month):

$\$ 0.1028 / \mathrm{kW}$

Based on historic average ratio of $\mathrm{kVar}$ to peak $\mathrm{kW}$

Total Facility charge $(\$ / \mathrm{kW} / \mathrm{month})$ :

1.6128

\footnotetext{
${ }^{18}$ SCE phone center message. March 2004.

${ }^{19}$ Nathan Smith, SCE, personal communication, July 2004.
} 
Time dependent demand charges $(\$ / \mathrm{kW} / \mathrm{month})$

On-peak summer:

Mid-peak summer:

Else:

Standby charge (\$/kW/meter/month)

Without direct access $(\$ / \mathrm{kV} /$ meter/month) $\quad 1.00$

Departing load $(\$ / \mathrm{kWh}$ from DER/month): $\quad 0.00191+0.00191=0.00382$

Add this to O\&M variable cost of each DG unit

Schedule SSGDR Simplified Self Generation Deferral Rate: not applicable ${ }^{20}$

The average percentage of DWR-supplied generation from July 20, 2003 to July 19, 2004 is $28.96 \%{ }^{21}$

Table A- 8 below, depicts the main components of the direct access and SCE TOU- 8 tariff rates. This tariff was filed January 22, 2004 and effective February 1, 2004. ${ }^{22}$

Table A- 8: SCE Schedule TOU-8, applicable for direct access and SCE TOU-8 tariffs SERVICE METERED AND DELIVERED AT VOLTAGES ABOVE $50 \mathrm{KV}$

\begin{tabular}{|c|c|c|c|c|c|c|c|c|c|}
\hline & \multicolumn{7}{|c|}{ Delivery Service } & \multicolumn{2}{|c|}{ Gen $^{\circ}$} \\
\hline & Trans & Distrbtn $^{2}$ & $\mathrm{NDC}^{3}$ & $\mathrm{PPPC}^{4}$ & PUCRF $^{J}$ & DWRBC $^{6}$ & Total $^{T}$ & URG & DWR \\
\hline \multicolumn{10}{|l|}{ Energy Charge - \$/kWh/Meter/Month } \\
\hline Summer Season - On-Peak & 0.00008 & 0.00449 & 0.00026 & 0.00191 & 0.00012 & $0.00493(1)$ & $0.01179(\mathrm{l})$ & 0.11413 & $0.08918(R)$ \\
\hline Mid-Peak & 0.00008 & 0.00449 & 0.00026 & 0.00191 & 0.00012 & $0.00493(\mathrm{I})$ & $0.01179(\mathrm{l})$ & 0.04314 & $0.08918(R)$ \\
\hline Off-Peak & 0.00008 & 0.00449 & 0.00026 & 0.00191 & 0.00012 & $0.00493(1)$ & $0.01179(\mathrm{I})$ & 0.03209 & $0.08918(R)$ \\
\hline Winter Season - On-Peak & $\mathrm{N} / \mathrm{A}$ & N/A & N/A & $\mathrm{N} / \mathrm{A}$ & N/A & N/A & N/A & N/A & N/A \\
\hline Mid-Peak & 0.00008 & 0.00449 & 0.00026 & 0.00191 & 0.00012 & $0.00493(1)$ & $0.01179(\mathrm{l})$ & 0.05200 & $0.08918(R)$ \\
\hline Off-Peak & 0.00008 & 0.00449 & 0.00026 & 0.00191 & 0.00012 & $0.00493(1)$ & $0.01179(\mathrm{I})$ & 0.03307 & $0.08918(\mathrm{R})$ \\
\hline Customer Charge - \$/Meter/Month & 0.00 & 224.22 & & & & & 224.22 & 125.23 & \\
\hline \multicolumn{10}{|c|}{ Demand Charge-S/kW of Billing Demand/Meter/Month } \\
\hline Facilities Related & 1.25 & 0.26 & & & & & 1.51 & 0.00 & \\
\hline \multicolumn{10}{|l|}{ Time Related } \\
\hline Summer Season - On-Peak & 0.00 & 5.30 & & & & & 5.30 & 8.10 & \\
\hline Mid-Peak & 0.00 & 0.46 & & & & & 0.46 & 1.57 & \\
\hline Off-Peak & 0.00 & 0.00 & & & & & 0.00 & 0.00 & \\
\hline Winter Season - On-Peak & N/A & N/A & & & & & N/A & N/A & \\
\hline Mid-Peak & 0.00 & 0.00 & & & & & 0.00 & 0.00 & \\
\hline Off-Peak & 0.00 & 0.00 & & & & & 0.00 & 0.00 & \\
\hline
\end{tabular}

\footnotetext{
${ }^{20}$ Not applicable for NBVC according to Nathan Smith at SCE. Personal communication on 16 July 2004

${ }^{21}$ Nathan Smith, SCE, email July 23, 2004.

${ }^{22}$ Schedule TOU-8, Time of Use, General Service Large. SCE website July 2004.
} 
Key:

Trans $=\quad$ Transmission and the Transmission Owners Tariff Charge Adjustments which are FERC approved.

Distrbtn $=$ Distribution

$\mathrm{NDC}=\quad$ Nuclear Decommissioning Charge

PPPC $=\quad$ Public Purpose Programs Charge

PUCRF $=\quad$ The PUC Reimbursement Fee is described in Schedule RF-E

DWRBC $=$ Department of Water Resources (DWR) Bond Charge.

Total $=\quad$ Total Delivery Service rates that are applicable to bundled service and direct access customers

Gen $=\quad$ Generation: the Gen rates are applicable only to Bundled Service Customers. When calculating the Energy Charge, the Gen portion is calculated as described in the Billing Calculation Special Condition of this Schedule.

Special Conditions:

Time periods are defined as follows:

On-peak: $\quad$ Noon to 6:00 pm summer weekdays except holidays

Mid-peak: $\quad$ 8:00 am to Noon and 6:00 pm to 11:00 pm summer weekdays except holidays

8:00 am to 9:00 pm winter weekdays except holidays

Off-peak: $\quad$ All other hours

The summer season shall commence at 12:00 am on the first Sunday in June and continue until 12:00 am of the first Sunday in October of each year. The winter season shall commence at 12:00 am on the first Sunday in October and continue until 12:00 am of the first Sunday in June of the following year. 


\section{G.1.3 Public Works flat rate}

The Public Works of NBVC recharges each building for electricity and gas at a flat that is quite different from the direct access tariff. Port Hueneme and Point Mugu each charges a unique rate to all buildings at each base. The NBVC Public Works Department bills Building 1512 at a flat rate of $\$ 133.49 / \mathrm{MWh}$ for electricity and $\$ 7.12 \mathrm{GJ}(\$ 7.51 / \mathrm{MBTU})$ for natural gas. There are no monthly customer or demand charges. Table A- 9 describes the energy and demand components for the Public Works flat rate electricity tariff.

Table A- 9: NBVC Public Works Tariff Charges for Port Hueneme Buildings

\begin{tabular}{|l|l|l|}
\hline & $\begin{array}{l}\text { Public Works Tariff } \\
\mathbf{( \$ / k W h )}\end{array}$ & $\begin{array}{l}\text { Total Demand Charges } \\
\mathbf{\$} / \mathbf{k W}\end{array}$ \\
\hline On Peak Summer & 0.13349 & 0 \\
\hline Mid Peak Summer & 0.13349 & 0 \\
\hline Off Peak Summer & 0.13349 & 0 \\
\hline On Peak Winter & 0.13349 & 0 \\
\hline Mid Peak Winter & 0.13349 & 0 \\
\hline Off Peak Winter & 0.13349 & 0 \\
\hline
\end{tabular}

\section{G.1.4 Direct supply}

Natural gas is obtained through the Defense Energy Support Center at Fort Belvoir, VA. Prices between August 2003 and September 2002 fluctuated from \$3.16/ GJ (\$3.330/ MBTU) to $\$ 6.63 / \mathrm{GJ}$ (\$6.99/MBTU), so an average price of \$5.11/GJ (\$5.39/MBTU) was used. SoCalGas's rate for delivery also varies monthly and is set at $\$ 0.95 / \mathrm{GJ}(\$ 1.00 / \mathrm{MBTU})$ based on the historic average. The total gas rate is $\$ 6.06 / \mathrm{GJ}$ (\$6.39/MBTU).

Figure A-3 below shows the commodity price of natural gas from the direct supply bills for the period September 2002 to August 2003. These costs do not include SoCalGas's transportation charge of $\$ 0.95 / \mathrm{GJ}(\$ 1.00 / \mathrm{MBTU})$. 
Distributed Energy Resources at Naval Base Ventura Country Building 1512

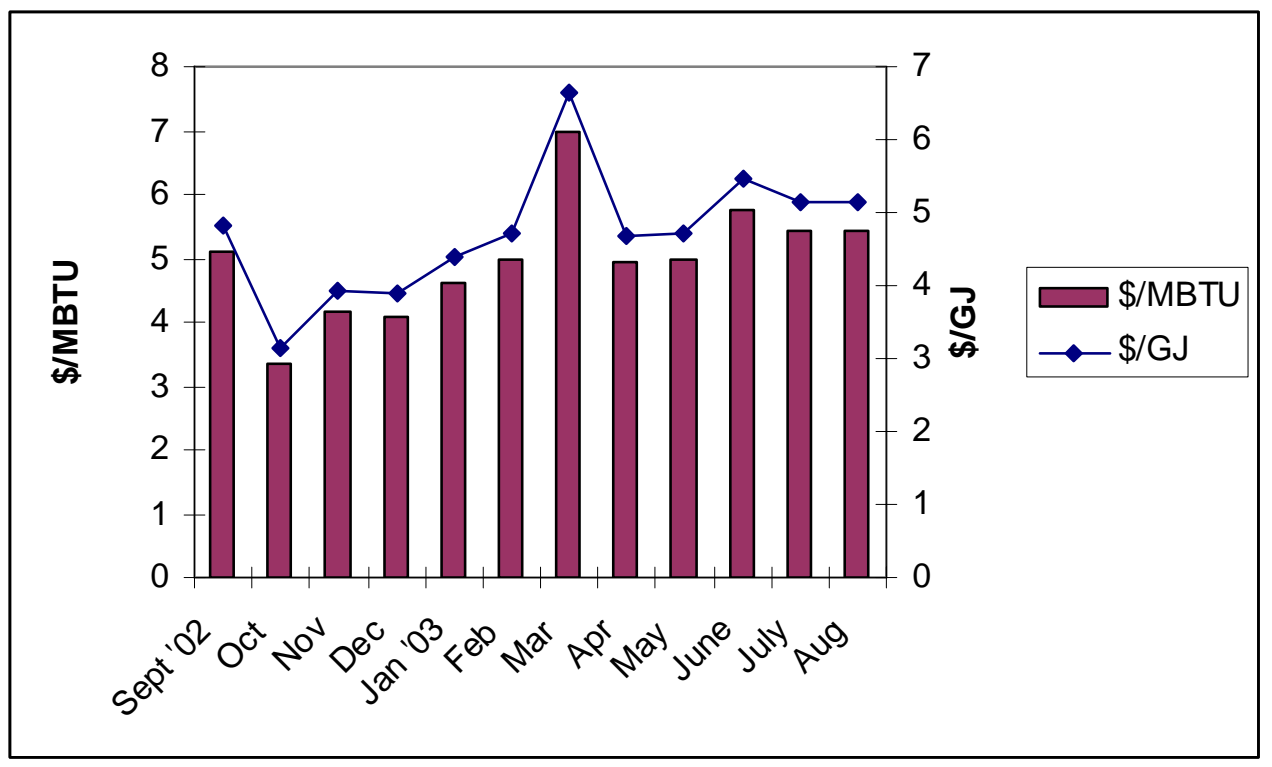

Figure A- 3: NBVC Natural Gas Commodity Prices 2002-2003 